\title{
Sociology of the Living Dead
}

\author{
by \\ Andrea Subissati, B.A. Hon. \\ A thesis submitted to the Faculty of \\ Graduate Studies and Research in partial fulfillment \\ of the requirements for the degree of \\ Master of Arts \\ Department of Sociology and Anthropology
}

Carleton University

OTTAWA, Ontario

July $29^{\text {th }} 2008$

(C) 2008, Andrea Subissati 


$\begin{array}{ll}\begin{array}{l}\text { Library and } \\ \text { Archives Canada }\end{array} & \begin{array}{l}\text { Bibliothèque et } \\ \text { Archives Canada }\end{array} \\ \begin{array}{l}\text { Published Heritage } \\ \text { Branch }\end{array} & \begin{array}{l}\text { Direction du } \\ \text { Patrimoine de l'édition }\end{array} \\ \begin{array}{l}\text { 395 Wellington Street } \\ \text { Ottawa ON K1A 0N4 } \\ \text { Canada }\end{array} & \begin{array}{l}\text { 395, rue Wellington } \\ \text { Ottawa ON K1A 0N4 } \\ \text { Canada }\end{array}\end{array}$

Your file Votre référence ISBN: 978-0-494-47644-4 Ourfile Notre référence ISBN: 978-0-494-47644-4

NOTICE:

The author has granted a nonexclusive license allowing Library and Archives Canada to reproduce, publish, archive, preserve, conserve, communicate to the public by telecommunication or on the Internet, loan, distribute and sell theses worldwide, for commercial or noncommercial purposes, in microform, paper, electronic and/or any other formats.

The author retains copyright ownership and moral rights in this thesis. Neither the thesis nor substantial extracts from it may be printed or otherwise reproduced without the author's permission.
AVIS:

L'auteur a accordé une licence non exclusive permettant à la Bibliothèque et Archives Canada de reproduire, publier, archiver, sauvegarder, conserver, transmettre au public par télécommunication ou par l'Internet, prêter, distribuer et vendre des thèses partout dans le monde, à des fins commerciales ou autres, sur support microforme, papier, électronique et/ou autres formats.

L'auteur conserve la propriété du droit d'auteur et des droits moraux qui protège cette thèse. $\mathrm{Ni}$ la thèse ni des extraits substantiels de celle-ci ne doivent être imprimés ou autrement reproduits sans son autorisation.
In compliance with the Canadian Privacy Act some supporting forms may have been removed from this thesis.

While these forms may be included in the document page count, their removal does not represent any loss of content from the thesis.
Conformément à la loi canadienne sur la protection de la vie privée, quelques formulaires secondaires ont été enlevés de cette thèse.

Bien que ces formulaires aient inclus dans la pagination, il n'y aura aucun contenu manquant.

\section{Canada}




\section{Abstract}

Horror films have a social function of speculating about societal fears and apprehensions. The current popularity of horror films featuring zombies is indicative of social tensions surrounding contemporary racism, globalization, and rampant Western consumption. In the films comprising George A. Romero's Dead series, the onslaught of the undead forces diverse people to come together and cooperate for survival. Differences between survivors become blurred when human value is reduced to one vital factor: humanity. However, these films show that social preoccupations of race, religion, class, etc. remain problematic, and often take precedence over the need for cooperation and resources for survival. Often, it is the remaining humans' failure to adjust to the changed social environment that brings about their violent demise. Cultural materialism as a method of inquiry seeks to describe the tensions that exist between culture as it is lived and culture as it is depicted in dominant media. This thesis will argue that these subversive films represent a scathing critique of the current state of affairs, which are interpreted in a variety of ways by an actively critical audience. The figure of the zombie is sociologically loaded; from its colonial origins in Haiti to continuing discourses of racism, savagery and otherness. Making use of cultural materialism and active audience theory, this thesis argues for the importance of Romero's Dead series as films that enable a critical assessment of our role in contemporary social practices of globalization and Western consumption, and speculate about the ending of our own narratives. 


\section{Acknowledgements}

I would like to sincerely thank my supervisor, Dr. Bruce Curtis, for his unflagging patience and encouragement. His confidence in this project has always struck me as simultaneously bewildering and delightful - much like Bruce himself.

I would also like to thank my exemplary colleagues in the Sociology department at Carleton University. I never hard to look very far for a proofreader, a book-lender, or a sympathetic ear: all of these were necessary for the completion of this thesis and the preservation of my sanity.

Finally, I would like to thank my parents for proudly telling their friends that their daughter was writing her thesis on the topic of zombies. 


\section{Table of Contents}

Introduction

............. 1

1. Cultural Materialism $\quad$............. 4

1.1 Raymond Williams $\quad$............... 4

1.2 Cultural Materialism $\quad$................. 9

1.3 The Horror Film $\quad$............... 14

1.4 The Active Audience $\quad \ldots \ldots \ldots \ldots . . . . \quad 20$

2. Night of the Living Dead $\quad$............. 30

2.1 A Haitian Zombie in Hollywood ............. 30

2.2 Night of the Living Dead: Authority, Racism, Culpability

2.3 Romero vs. Russo; the $30^{\text {th }}$ Anniversary Edition

3. Day of the Dead, Dawn of the Dead

3.1 Dawn of the Dead $\quad$.............. 53

3.2 Day of the Dead $\quad \ldots \ldots \ldots \ldots . . . . .67$

4. Conclusion $\quad \ldots \ldots \ldots \ldots . . . . . \quad 78$

4.1 George A. Romero's Land of the Dead and Diary of the Dead

4.2 Conclusion $\quad \ldots \ldots \ldots \ldots \ldots . . . .62$ 


\section{Introduction}

Horror movies are often dismissed by mainstream culture as lowbrow; it is as if horror movie fanatics lack the intellect to appreciate finer forms of cinema, and seek their jollies in campy violence and gore. But there is more to horror movies than two stars out of five and an ' $R$ ' rating. To the critical viewer, horror movies are a window into the darker side of social life: the skeletons in the social closet, the things that go bump in the night. As Tudor writes, "Fictions are understood and experienced in variable cultural settings, read by different audiences in different ways and can only be explored for their social significance by seeking to understand them in those contexts" (1989: 211). Thus, horror movies can be conceived of as collective nightmares: compiled representations of all the things that both terrify and intrigue us at the same time. Moreover, as Raymond Williams would argue, horror films contain ideological elements that are constantly being negotiated and redefined by their active and critical viewers. His method, cultural materialism, seeks to describe the tension between culture as it is depicted in film and culture as it is lived in reality, isolating hegemonic tenets that reify dominant culture.

Fear and fascination are among the most interesting forms of human response, and there is no horror movie monster as captivating and as socially relevant as the undead flesh-eating zombie of George A. Romero's Dead series. There is more to the zombie than meets the cinema; the American myth of the walking dead was inspired by real accounts of people rising from the grave. Wade Davis's famed ethnography Passage of Darkness (1988) provides an in-depth account of zombification (the process of turning one into a zombie) among the Vodoun in Haiti. As will be discussed later, the Haitian Vodoun zombie differs substantially from the zombies we Westerners know from late- 
night "splatter movies". The American zombie is depicted as a bloodthirsty menace: a living corpse, whose only motivation is to spread its condition throughout the entire population. The differences between the fictional Western zombie and the actual Haitian Vodoun zombie are sociologically significant in that they expose ideological themes unique to Western society. In this way, the 'Americanization' of the Haitian Vodoun zombie can be understood as indicative of Western hegemonic fears and anxieties, apprehensions and fascinations.

George A. Romero's Dead series carries the sociological figure of the zombie into haunting narratives of desperate groups of humans who find themselves trapped in social traditions and conventions such that they cannot escape the undead rising. Beginning with Night of the Living Dead and continuing with Dawn of the Dead and Day of the Dead, Romero's films frighten us in two ways: by portraying a mindless undead monster set loose upon society, and by showing a society completely unable to survive the onslaught due to its members' inability to cooperate. The films draw attention to aspects of our culture that have saturated our everyday lives to the point that we no longer notice them. While in the West we live in relative comfort and security, Romero's films show how easily our current social structure can be dismantled.

This thesis will begin by outlining Raymond Williams's cultural materialism as a mode of inquiry by describing its beginnings as an alternative form of literary criticism to "Cambridge English". Active audience theory will also be discussed in this chapter, focusing on the contributions of Hall, Morley and Fiske. It will be argued that audience reception and interpretation are necessary components of any argument toward the social importance of a cultural text. The second chapter will introduce the zombie, starting from 
its origins among the Vodoun community in Haiti. It will be shown that Romero's modifications to the original mythical monster are culturally significant and appropriate for the social critique found in his films. The remainder of that chapter as well as chapter three will provide a cultural materialist analysis of the first three films of George A. Romero's Dead series while situating them within their historical context. The conclusion will summarize and briefly discuss Romero's latest two installments of the series. Overall, this thesis aims to contribute to the ever-growing list of published analyses of Romero's films by providing a textual analysis while maintaining an emphasis on audience reception and Marxist critique. 


\section{Chapter 1 - Cultural Materialism}

\section{I - Raymond Williams}

Raymond Williams is recognized as a founding figure in the development of cultural studies. His fundamental contribution was in his blending of Cambridge literary criticism with Marxist critique, resulting in what is currently known as cultural materialism. Cultural materialism, as we will see, is more an analytical standpoint than a methodology, one which locates the text in its historical context while retaining the Marxist emphasis on class conflict and exploitation. This chapter will outline Williams's development of cultural materialism, giving a background of his difficulties, and eventual break with orthodox Marxist literary analysis. Williams was primarily concerned with literature and drama, but his later writing reveals an interest in what he called "the powerful arts of film and broadcasting" (1980: 45). Recent years have seen a resurgence in horror films featuring zombies: mindless, lurching corpses that feed on the flesh of the living. George A. Romero's Dead series stands out among zombie films for its social commentary on contemporary Western culture, including capitalism, consumerism, globalization, and social stratification. This section will discuss why these films are suitable cultural texts for cultural materialist analysis with reference to cultural hegemony and incorporation.

At the time of his undergraduate studies, Raymond Williams was what his peers referred to as a 'scholarship boy': an allusion to his working class status and the fact that he earned his way into post-secondary education through scholarships (Higgins, 1999: 6). He began his English degree at Cambridge in 1939. As an undergraduate, Williams was 
dissatisfied with what he called "Cambridge English": a stream of literary criticism founded by F.R. Leavis that focused on the interrelatedness of culture and society. Leavis held that the importance of literature lay in its ability to express life as it is lived: "the major novelists... count in the same ways as the major poets, in the sense that they are significant in terms of that human awareness they promote; awareness of the possibilities of life" (1962: 10). Leavis was not a Marxist, but it was his anti-utilitarian criticism that inspired Williams: “It was the range of Leavis's attacks on academicism, on Bloomsbury, on metropolitan literary culture, on the commercial press, on advertising, that first took me" (Williams, 1979: 65-6). Williams agreed that literature of a given period is importantly connected to the lived reality of that period, but found himself opposed to Leavis with regard to the relationship between culture and the more basic, mechanical aspects of society. Leavis saw modernization processes to be indicative of a period of cultural decline, and viewed prior forms of literature with a kind of academic nostalgia.

While Leavis saw art and culture as having importance beyond the mechanical workings of civilization, Williams saw them as importantly and inexorably linked. Williams was an active member of the Socialist Club on campus, but despite his overt leanings to the Left, Williams sharply criticized his colleagues who applied Marxist literary analysis to literature. The critical literary trend of the time was "proleptic criticism," in which literature of the past and present is evaluated in terms of how it depicts a possible future in line with Marxist ideals of revolution. The realist movement was criticized for depicting a solely Bourgeois reality: "an idea of society as a neutral area within which each individual is free to pursue his own development by his own advantage as a natural right" (1958: 326). A "new realism," as touted by Ralph Fox in 
The Novel and the People, must embrace the leftist sentiment that the working man is able "to change his conditions, to master life" and has the means to "become the lord of his own destiny" (1937: 100). Williams took issue with "socialist realism" because he found such analysis deterministic, and too rigidly bound to a set of established conventions. He found that dogmatic prescriptive analyses of realism led one into economic determinism as well as "romantic idealism" (Williams, 1963: 250). For Williams, what was missing in Marxist literary analysis was a conception of society as a whole, and not the two-tiered economy-determining-superstructure model. His combined dissatisfaction with "Cambridge English" and British Marxism led him to a painful intellectual impasse. In Politics and Letters, he describes his frustration in trying to reconcile his position with his teacher at Cambridge, E.M.W. Tillyard:

I was engaged in having to satisfy somebody who was professionally teaching a subject that my ideas were tenable and reasonable, and I could not. I was continually found out in ignorance, found out in confusion... You must remember that a hell of a lot of my self-image was devoted to the notion that I could handle academic work. It now became clear to me that I could not.

Williams's draft into the British army in July of 1941 provided him with temporary relief from his crisis of intellectual self-identity. He served four years in the Second World War before returning to Cambridge. Upon his return, Williams and some like-minded colleagues started a left-wing literary review journal called Politics and Letters, which ran for four issues. The journal sought to define itself in opposition to three major streams of thought that dominated literary analysis. The journal's primary stance was an outright rejection of the Marxist literary movement of the 1930's, which Williams believed to have failed in its attempt to formulate legitimate Marxist criteria for 
criticism. Second, Politics and Letters rejected the cultural elitism of Leavis' journal Scrutiny, which was considered key to literary studies at the time. Finally, the journal attacked Cyril Connolly in his dismissal of the relationship between modern literature and culture in his journal Horizon. The tacit mission of Politics and Letters was effectively to bridge literary analysis with a leftist political stance in order to mobilize an intelligent and critical reading public. In the end, Politics and Letters was unable to withstand the tension between the needs of material survival and the political commitment to foster social responsibility due to an inadequate conceptualization of politics (Higgins, 1999: 11), which served to reproduce Williams's frustrations; Politics and Letters collapsed in 1948.

Following completion of his M.A., Williarns taught adult education in English for several years. He published his influential text Culture and Society in 1958, establishing his reputation as a leading figure in the field of cultural studies. The book was successful despite its clear political bias toward the Left and its opposition to the "Cambridge English" he had encountered as a student. Williams was greatly concerned by the manner in which Cambridge English conceptualized "the masses" as a negative force in society; the harbinger of crude popular culture. In Culture and Society, Williams points out that common usage of the term depicts the working public as fickle, uncritical and of general low taste: even dangerous, synonymous with the term "mob" (1958: 298). Williams demonstrates his commitment to his adult education students and to his Marxist background by challenging these disparaging definitions, pointing out that massdemocracy is just proper democracy. He writes,

Our normal public conception of an individual person, for example, is 'the man in the street'. But nobody feels himself to be the man in the street; we 
all know much more about ourselves than that. The man in the street is a collective image, but we know, all the time, our own difference from him. It is the same with 'the public', which includes us, but yet is not us. 'Masses' is a little more complicated, yet similar. I do not think of my relatives, friends, neighbors, colleagues, acquaintances, as masses; we none of us can or do. The masses are always the others, whom we don't know, and can't know. Yet now, in our kind of society, we see these others regularly, in their myriad variations; stand, physically, beside them. They are here and we are here with them. And that we are with them is of course the whole point. To other people, we also are masses. Masses are other people.

(1958: 299-300)

If there are no masses, only ways of seeing people as masses, this misrepresentation of the working public is little more than a convenient way of distancing oneself from others for the purposes of cultural or political exploitation. From here, Williams goes on to formulate his most important and innovative argument in the book. He points out that the masses were being blamed for the so-called crudeness of popular culture (radio, movies, and tabloids) when they did not, in fact, have the means to create these new media institutions (308). For this reason, any attempt to criticize the common people of a society based on popular culture is deeply mistaken; the real issues are the intentions of the producers of popular culture and their relationship with the larger society (308). This is a far more complex question for Williams, who is unwilling to dismiss the working class as the mindless dupe of ideological manipulation, or to accept that popular culture is representative and unfettered of working class life. This question of the nature of the relationship between culture and cultural production became the foundation for his retooling of orthodox Marxist cultural analysis toward a methodology he would call cultural materialism. 


\section{II - Cultural Materialism}

The success of Culture and Society and The Long Revolution (1961) earned Williams a professorship back at Cambridge in Drama where he would continue to lecture and write on the complexities of the relationship between literature and culture until his retirement in 1983. In "Base and Superstructure in Marxist Cultural Theory," Williams argues that the relationship between the representations in popular culture and the actual lived experience of the common people of that culture share a complex relationship: one that problematizes certain aspects of Marx's original base/superstructure model (1980: 32). The base, he argues, is a process rather than a state, and does not form a concrete reflection in an identical superstructure, as the model suggests (33). Williams argues for a broader conception of the term 'determination' to mean "setting limits, exerting pressures" rather than a deliberate forcing of will (32). He points out importantly that Marx himself did not intend for the concept of base to refer only to productive forces in industry and capitalist commodity production, but to include a range of productive forces, including the social and cultural: “...the most important thing a worker ever produces is himself, himself in the kind of labour, or the broader historical emphasis of men producing themselves, themselves and their history" (33). If we conceptualize the superstructure also as a productive force, it is no longer secondary, or 'determined' by the mode of production (35)

In lieu of the formative one-way model of the economic base determining the cultural superstructure, Williams argues that "social being determines consciousness." (32). To put it this way is to emphasize the multifarious influences on social life that are lived, and not just observed and adopted; society is best understood as a conceptual whole 
rather than as a two-tiered system. Williams borrows the idea of social totality from Georg Lukács in advancing this position: "The totality of social practices was opposed to this layered notion of base and a consequent superstructure. This concept of a totality of practices is compatible with the notion of a social being determining consciousness, but it does not necessarily interpret this process in terms of a base and a superstructure" (35). Here, Williams stresses that to complicate the language of determination is not to do away with the importance of intention; to do so, he warns, drains the question of any Marxist claims of class domination entirely.

For while it is true that any society is a complex whole of such practices, it is also true that any society has a specific organization, a specific structure, and that the principles of this organization and structure can be seen as directly related to certain social intentions, intentions by which we define the society, intentions which in all our experience have been the rule of a particular class. These laws, constitutions, theories, ideologies, which are so often claimed as natural, or as having universal validity or significance, simply have to be seen as expressing and ratifying the domination of a particular class.

To help describe the complex relationship between cultural artifacts and culture as it is lived, Williams draws from Gramsci's concept of hegemony. In hegemony, Williams is able to synthesize Lukacs's conception of a social totality with Marxist emphasis of intention. Hegemony refers to the ongoing processes by which the dominant group is able to saturate the consciousness of the subordinate group for purposes of ideological coercion (Gramsci, 1971: 258). For Williams, the usefulness of this concept is in its ability to conceptualize the limits and pressures exerted by the powerful segment of society and their relationship to the lived practices of the subordinate class as an ongoing struggle within a social whole. As he writes, 
For hegemony supposes the existence of something which is truly total, which is not merely secondary or superstructural, like the weak sense of ideology, but which is lived at such a depth, which saturates the society to such an extent, and which, as Gramsci put it, even constitutes the substance and limit of common sense for most people under its sway, that it corresponds to the reality of social experience very much more clearly than any notions derived from the formula of base and superstructure.

(Williams, 1980: 37)

The idea of dominant ideology being able to saturate the consciousness of society to the extent of everyday practices and understandings of 'common sense' was useful to Williams in that it emphasized that these processes are not merely superstructural; they occur within a social totality (37). Among the ways in which hegemony functions in society is through selective tradition, wherein certain lived practices are passed off as normal and eternal, while other practices are excluded. It is this idea of selectivity that interests Williams because it points to his previous struggles with applying Marxist questions of intention to literature. If the social institutions that hold the most power over a population (i.e. family, education,) are the ones that involve practices which are lived day-to-day, "all these forces are involved in a continual making and remaking of an effective dominant culture, and on them, as experienced, as built into our living, its reality depends" (39). It is precisely this lived-ness of ideology that ingrains dominant culture in society and is subsequently difficult to overthrow.

Williams distinguishes challenges to dominant culture as residual or emergent. Residual forms refer to activities that were practiced in some previous social formation that somehow linger into the present one. Emergent practices, on the other hand, are the "new meanings and values, new practices, new significances and experiences, [which] are continually being created" (41). Williams argues that while alternative and 
oppositional practices do occur, they are contained and controlled insofar as they can be socially accommodated within the dominant culture. He gives the example of parliamentary politics where the internal conflicts are real, but remain bounded by very specific and precise corporate definitions (40). He writes, "There is a very simple theoretical distinction between alternative and oppositional, that is to say between someone who simply finds a different way to live and wishes to be left alone with it, and someone who finds a different way to live and wants to change society in its light" (4142). Whether or not alternative or oppositional cultures are able to sustain themselves in society depends on their compatibility with the dominant system. In his words, "In capitalist practice, if the thing is not making a profit, or is it is not being widely circulated, then it can for some time be overlooked, at least while it remains alternative. When it becomes oppositional in an explicit way, it does of course, get approached or attacked." (43) By "approached" Williams is referring to a process of "incorporation," whereby dominant culture incorporates certain aspects of alternative or oppositional culture by ascribing meaning to them that corresponds with dominant ideology (41). Western Amish communities are examples of sustainable alternative culture. These communities are able to exist without interference from dominant culture because dominant ideology is not threatened by them; in fact, the Amish lifestyle is often mocked in popular Western culture for its rejection of modern technology and lifestyle.

Oppositional, anti-establishment subcultures (i.e. punk) are dismantled via incorporation; defining characteristics of the movement such as the Mohawk or distinctive clothing styles are incorporated into the mainstream, losing their oppositional quality. Thus, the 
sustainability of an alternative or oppositional culture depends on its compatibility with the dominant ideology of a culture, or its susceptibility to incorporation.

To summarize, cultural materialism is a method of inquiry that seeks to explore the relationship between the limits and pressures exerted by the dominant class and the lived reality of the working class of that culture. Their relationship is not rigidly deterministic or unidirectional, but rather is defined by ongoing struggles and challenges. As a method, cultural materialism seeks to isolate hegemonic aspects of a cultural text that reflect that text's incorporation by elite institutions to influence or justify dominant values upon that culture. Williams focused his inquiry on dramatic literature primarily, but includes mention of visual arts, music and "the powerful arts of films and of broadcasting" (45). As I will demonstrate in the following section, the recent increase in modern horror films featuring zombies can be understood as an emergent challenge to dominant consumerist ideology in the films' depiction of a post-apocalyptic society, where the dominant ideology of individualism and consumerism has humanity literally consuming itself to the point of devastation. George A. Romero's films portray shellshocked men and women who are unable to cooperate enough to survive an undead onslaught. Thus, zombie films not only question the sustainability of the ideological American Dream, they overtly depict its societal result to be harmful and destructive. Furthermore, as cultural materialism argues for a state of tension between culture as it is lived and culture as it is depicted, these films not only provoke critical thought, they also serve to influence the way we interpret our everyday lives in the West. 


\section{III - The Horror Film}

This section will begin with an overview of the existing work done linking horror film to society, starting with a thematic overview of horror films, before moving on to a discussion of the leading proponents of active audience theory. In Western culture, the cinema is both pedagogue and demagogue, and Williams was right to call it "powerful" (1980: 45). When Williams studied in the 1940s, Marxist literary critics sought to dismantle the dominant ideological content in literature that portrays Bourgeois values as natural, eternal, and commonsensical. Today, more than 100 years after the emergence of the motion picture, major high-budget films continue to portray a reality that reflects contemporary culture. Marxist analysis of film is common, but with a contemporary focus on exposing racist and sexist themes as well as those which perpetuate class-based exploitation (Wood, 1979: 7). Film criticism often combines a critical Marxist position with Freud's psychoanalytic theory of repression, wherein films are believed to be sublimations of the undesirable urges we naturally repress (9). Psychoanalytic theory enhances our understanding of how 'the Other' is depicted and understood in popular film as the embodiment of that which dominant culture does not wish to endorse. Robin Wood lists women, children, ethnic minorities and the proletariat as examples of figures that are Othered in film (9). Applied to horror film, the difference of the Other is exaggerated to the point of monstrosity, but this paper will show that George A. Romero's films featuring zombies suggest that humanity may be more monstrous than the living dead.

Following cultural materialism, the key to understanding a horror film within its genre is to locate it historically among other horror films of that time, but this is 
problematic in the case of horror films for two reasons. First is a matter of definition. The horror film genre is notoriously difficult to break down into essential components, and film critics have debated characterization for decades (Jancovich, 2002: 7). Within these debates, there is often insidious slippage of terms like 'horror', 'fantasy', and 'Gothic', as well as mention of vague subgenres such as the 'slasher' film, the 'splatter' film, and 'thrillers'. Such difficulties in definition inevitably lead to problems of selectivity and exclusion. Mark Jancovich notes that film critics often choose one aspect of the genre (the one they personally prefer) upon which to base their analysis, downplaying the importance of those films that do not conform to their model (2002: 9). For example, the film academic who particularly reveres the work of Alfred Hitchcock might portray horror films from the 1980s poorly in comparison, and may write that the entire genre is in decline. This is not purely a matter of subjectivity: but an issue of comparing films across context.

The second difficulty with horror film genealogies is in determining which films are weighted with being indicative of a trend or shift in the genre (2002: 8). As Jancovich points out: "Critics looking at the 1930s have often taken classics such as Dracula or Frankenstein as representative examples, when the very features that have resulted in their class status might not make them representative at all" (2002: 9). It would be impossible to consider every horror film ever made (especially considering the aforementioned slippage of terminology), and the criteria for noteworthy films are often reduced to box office success, DVD sales, or academic scrutiny. Thus, film histories become histories of production, and not of equally important reception, mediation or consumption (2002: 10). This is not to say that film histories are useless: they enable us 
to locate the social apprehensions depicted in these films in their historical context, but since no one genealogy should be understood as an authoritative account of a genre, the film history laid out in this chapter is intentionally provisional.

Mark Jancovich locates the beginning of horror film with Méliès' motion picture A Trip to the Moon (1902), which was the first to employ trick photography to depict impossible images never before seen beyond the imagination (2002: 3 ). This otherworldly interest gave rise to the German expressionist film movement which was defined by its commitment to an anti-realist, artistic aesthetic. The importance of this movement was in its willingness to break from conventional slapstick filmmaking in order to appeal to high-class viewers: to "make the cinema respectable for bourgeois audiences, and give it the status of art" (Elssaeser, 1989: 32). The budding elite status of cinema saw the dominance of American Hollywood film in the 1930s; many horror film historians begin their genealogies here. Films based on Gothic literature, such as James Whale's Frankenstein (1931) and Tod Browning's Dracula (1931) made cultural icons of actors Boris Karloff and Bela Lugosi, as well as establishing the tragic "monster" as the central feature of the emergent horror genre (Jancovich, 2002: 3). Val Lewton's films in the early 1940 s brought the other-worldly threats of these classic monsters closer to home. Jancovich writes: "Despite their Gothic elements, these films often located their narratives within a recognizably modern world... In other words, the horror no longer takes place in some exotic never-never land, but erupts within the normal and the everyday" (3).

Throughout the 1940s and 1950s, horror film took on a decidedly sci-fi flavour, tackling topics such as alien invaders from outer space (The Thing from Another World 
[1951], Invasion of the Body Snatchers [1956]) as well as normal earth animals growing to fantastic sizes due to nuclear radiation or human experimentation (Them! [1954], Tarantula [1955]) (2002: 4). Horror film historian Andrew Tudor argues that this tendency is reflective of the positivist boom of the 1950s and the emerging interest in outer space (1989: 39). At this time, horror movies were greatly influenced by UK-based Hammer Film Productions, which made its mark on film history with its emphasis on vivid imagery, and a level of gore considered shocking by audiences of its time (Jancovich, 2002: 4).

In the 1960s, horror film became less other-worldly and hit closer to home. Alfred Hitchcock's seminal film Psycho (1960) is recognized by many film historians as being tremendously influential upon the horror film genre in two ways. First is its setting in the ordinary everyday. Tudor's historical analysis shows that horror films in the 1960s increasingly used plotlines about psychotic people and sexual deviants, ostensibly due to the discourse surrounding homosexuality, which was becoming overt at the time (1989: 27). In Psycho, Norman Bates watches victim Marian shower before he invades her room to stab her to death. Psycho's second notable contribution to the genre is that it is also credited with starting a trend of plotlines surrounding a very intimate social relationship: the family (Jancovich, 2002: 4). Subsequent 'family horror films' of the late 1960s and early 1970s such as Tobe Hooper's The Texas Chainsaw Massacre (1974), Wes Craven's The Hills Have Eyes (1977), and George A. Romero's Night of the Living Dead (1968), all include familial themes (2002: 5).

In order to outdo previous films, horror plotlines continually delved deeper into the social psyche, invading taboo spaces that were thought to be safe. The 'slasher movie' 
craze of the late 1970s and 1980s, in particular, is a notable turning point in the horror movie genre. Slasher movies can be defined by a suspenseful plot wherein a violent murderer ("slasher") stalks and terrorizes a group of teenagers and proceeds to kill them off one by one (2002: 5). The overt sexuality and drug use in these films exposed the entire horror genre to severe criticism. Slasher films were lambasted because they encouraged identification with the murderer as well as the victims. In John Carpenter's Halloween (1978), for example, the famous opening scene features a sequence where we literally experience the murderer's point of view through Michael Meyer's mask. The technological advent of home video allowed low-budget, independent filmmakers to penetrate the market.

Horror movies became fodder for an emergent audience which was bored with mainstream, standardized entertainment. The monster is no longer the isolated, tragic victim that it was in the past; rather, it is the state of humanity, with which the monster is at odds, that is depicted as tragic and ironic. Sometimes the dead who return are romanticized (as is the case with the films Ghost ([1990] and Truly, Madly, Deeply [1991] or eroticized (see Interview with the Vampire [1994] or Bram Stoker's Dracula [1992], but since the 1990s, the undead monsters of horror movies are simply monstrous. Some film and popular culture theorists isolate this shift as a move from modern film to postmodern film, and argue that this has radically changed the narrative conventions of the horror film genre (Newman, 1988; Modleski, 1986). Pinedo describes this change in narrative structure as marking a lack of confidence in humanity to quash the supernatural threat, a sentiment echoed by director George Romero, as we will see in the next section. Pinedo writes, "The trajectory of the classical narrative is to deploy science and force... 
to restore the rational, normative order, whereas the postmodern narrative is generally unable to overcome the irrational, chaotic forces of disruption" (1997: 23). Such films generally end either ambiguously or ominously, with a marked failure to return things to their normal state (16). Thus, horror movies are no longer bounded with the obligation of closure; explanation and resolution are no longer necessary components of the plot. The postmodern horror film "throws into question our assumptions about reality and unreality" (18). Combined with the everyday uncertainties of postmodernity as it is lived, postmodern horror movies are arguably scarier than ever, leaving the audience with lingering concerns about the issues brought up in the film.

Night of the Living Dead came out in 1968, ten years before the development of gory, slasher films as a genre, but it is noteworthy that the film's home video success in later years greatly surpassed its original box office earnings. Night of the Living Dead earned credibility with horror audiences for its low-budget production and its cast of relatively unknown actors. Romero's entire Dead series is replete with cameos by Romero himself, his wife Chris, and special effects make-up technician Tom Savini: a horror film tradition begun by Alfred Hitchcock and continued by authors and screenwriters such as Stephen King and M. Night Shyamalan. There is an element of community among Romero fans; people "in the know" who recognize these cameos. Following the success of Night of the Living Dead, Romero made four related films (not quite sequels: alternate storylines along the same undead apocalypse) titled Dawn of the Dead (1978), Day of the Dead (1985), Land of the Dead (2005) and Diary of the Dead (2008). Subsequent years saw many horror films featuring zombies, including Tombs of the Blind Dead (1971), Zombi 2 (1979), Hell of the Living Dead (1980), The Evil Dead 
(1981), Night of the Creeps (1986), 28 Days Later (2002) and the Resident Evil films (2002, 2004, and 2007). Comparatively speaking, prior to Night of the Living Dead, zombie movies such as White Zombie (1932) and I Walked with a Zombie (1943) took place in removed environments overseas. Romero's films bring the horror closer to home in two ways: by situating the storylines in private backyards and by altering several characteristics of the Vodoun zombie that appeared in previous zombie films in culturally significant ways (as is discussed further in the next chapter). While not everyone who has seen the films turns into an all-out zombie fanatic, at the very least these films inspire critical thinking about contemporary Western life and the direction we are moving toward as a society. As these films challenge the existing status quo, they represent oppositional cultural forms: forms which seek to overthrow the current state of affairs by dismantling the fundamental hegemonic notions underpinning it.

\section{IV - The Active Audience}

Following Raymond Williams, active audience theorists challenge the notion that messages conveyed in media are static infusions of meaning; a 'hypodermic needle' model of communication where a message is involuntarily injected into the audiences, who have no agency in the matter. They believe that there are numerous other factors involved in what and how audiences absorb what they do from given pieces of media. "Fictions are understood and experienced in variable cultural settings, read by audiences in different ways and can only be explored for their social significance by seeking to understand them in those contexts" (Tudor, 1989: 211). Prior to the emergence of active audience theories in the 1970s, reception studies were dominated by models of 
behaviourism, wherein scientists can determine the 'effect' of a given message by empirically observing the ensuing behaviour of the subject (Staiger, 2005: 5). Belief in behaviourism led to analogies of the audience as 'mindless dupes', helpless to the pervasive 'hypodermic needle' of mass media; "a simple stimulus-response approach which imagines the media as a kind of narcotic and the relationship between media/audience as one where audiences can...be straightforwardly 'injected' with a message" (Brooker \& Jermyn, 2003: 6). This model rings of empiricism with its insistence on observable evidence and the goal of finding a universal claim to apply to regulation of media. Staunch behaviourism has been largely discredited in the field of reception studies, but it reappears occasionally at times of crisis or tragedy (i.e. Marilyn Manson said to be to blame for 1999 shootings at Columbine). The label of 'mindless dupe' is obviously unflattering, and the behaviourist 'effect' model gave way to uses and gratifications theory, which sparked the beginning of the active audience debate (Staiger, 2005: 52). According to uses and gratifications theory, the viewer does have some agency in which messages get through, and which are ignored. At last, the audience gets some recognition: "the uses and gratifications approach to audiences credits them with being 'active' and/or discriminating in their engagement with the media in a way not envisioned by the effects model" (Brooker \& Jermyn, 2003: 9). Thus, uses and gratifications theory gave audiences some agency in message reception, but this approach still held to the simple model of message transmission: top-to-bottom, TV-to-viewer. Active audience theory differs from both the behaviourist model and the uses and gratifications model by radically altering the aforementioned model of message transmission. Rather than a one-way transmission of meaning, active audience theorists 
"propose a two-way relationship between audiences and tests whereby readers can resist, engage with and create their own meanings from the culture they receive from 'above"' (2003: 91). Active audience theory introduces the idea of reception into the social sciences, where issues of power, production and capital can enter more meaningfully into the equation (Staiger, 2005: 77).

Like Raymond Williams, Stuart Hall was at pains to dismiss the concept of the mindless masses, to provide "an antidote to the blank social subject constructed by behaviourism" (Rojek, 2003: 95). In fact, Hall worked alongside Williams himself on the New Left Review in the 1950s and 60s. Hall believed that the interpretation of the reader depended on its social location; those who were aligned with the dominant ideology would likely adopt dominant readings, and those who found themselves in opposition would adopt oppositional ones. He proposed a typology of four codes in which a given viewer might find itself located when decoding a message; the dominant/hegemonic code, the professional code, the negotiated code and the oppositional code. The dominant/hegemonic code is realized when audiences take in media messages unquestioningly as literal reflections of reality, "in which the critical reflexivity of the audience is suspended or at least decisively checked" (97). While his emphasis is on the active, discriminating viewer, he includes the dominant reading code as a possibility. The professional code refers to the practices of the "media professional" in obscuring their ideological biases (97). He claims that "media professionals are organically linked with dominant elites through the structural position of the media as an ideological apparatus, and their privileged access to elite constructions of reality" (97). Thus, the professional code is compliant with the dominant/hegemonic code in producing what Hall terms the 
'preferred reading'. The negotiated code, on the other hand, takes questions of reflexivity into account. Following this code, the audience is aware of the ideological context of media messages and approaches them with some measure of suspicion (98). "The negotiated code reflects high levels of ambivalence and inconsistency about political, economic and cultural matters"(98). The fourth code, the oppositional, describes what is referred to by some as the 'boomerang effect': "where the 'intended' meaning of a media test can be turned around by members of its audience who read it in a way which positively reverses the intended meaning" (Brooker \& Jermyn, 2003, 9). It is here that we see the audience conceptualized as active, reflexive and resisting (Rojek, 2003: 98). The question of intention is thus very important to any analysis of cultural texts and what is read from them; one cannot argue that these films are interpreted in opposition to dominant culture or in opposition to the filmmaker without some idea of what the filmmaker intended to project. Thanks to commentary tracks available on DVD versions of the films, this thesis is able to make use of concrete evidence that social satire was intended in these films on the part of the director. This thesis will make use of the dominant code/preferred reading and the oppositional code, as they represent directly observable leanings on behalf of the viewer. The professional code is too similar to the dominant code to warrant separate analysis, and while it is worth acknowledging that undetermined and ambivalent readings can and do occur, the negotiated code is too irresolute to be analytically useful. Hall's four typified codes are rudimentary, which he himself admits (101), but they do provide the study of media reception with a theoretical basis upon which we can begin to question how messages are transmitted and how they might be contested. 
David Morley draws from the work of Stuart Hall by starting with recognition of the influence of dominant ideology and the consumptive processes of entertainment media but takes aim at the messages of television (Morley, 1992: 8). Morley proposes a twofold methodology in the search for reception: semiotics and sociology (75). Semiotics, broadly defined, refers to the study of how language shapes knowledge through the construction of meaning. Language is a necessarily social phenomenon, in that meanings of words must be agreed upon unanimously among all members of a society in order for there to be meaningful communication. In terms of reception theory, the use of semiotics elucidates "the internal structures and mechanisms of the test/message/programme which invite certain readings and block others" (75). Thus, what is said is only important insofar as how it is understood. The sociological dimension refers to the significance of an audience/viewer's cultural makeup, including such sociodemographics as age, race, sex and class, in constructing differential interpretations of messages (75). Morley argues that these two factors taken together can provide a more systematic way of understanding reader response while avoiding the traps of determinism and total relativism (75). Messages are understood to be supplemental to a viewer's existing reservoir of knowledge. Morley writes that media messages "intersect with other messages that we have received - explicit and implicit messages from other institutions, people we know, or course of information we trust" (77).

John Fiske adopts Hall's and Morley's suspicion of preferred readings embedded in mass media, and agrees that they are negotiated at the site of reception. He writes “ there are preferred meanings inherent in every message. But even preferred meanings, which usually coincide with the perceptions of the dominant sections of society, must 
compete with and be seen in the context of other ways of seeing" (18). He calls for content analysis of television media to be focused on both the explicit as well as the implicit meanings, and advocates the use of semiotics (38). In "Understanding Popular Culture" (2003) Fiske explores the idea of resistance against the commodification of popular culture with the example of ripped jeans. As a significant cultural artifact of the West, blue jeans are imbued with both material meaning (jeans are resilient, and keep our legs warm), and cultural meaning (referring to stylistic differences between ripped jeans, tight jeans, baggy jeans, etc). He proposes that the wearing of ripped jeans signifies resistance on the part of the wearer in that it indicates their preference to wear "ruined" jeans over purchasing new ones. Predictably enough, denim designers adopt this grassroots style and begin manufacturing pre-torn jeans with the "worn-in" look that has since become popular. This example effectively demonstrates the push-pull relationship between society that produces popular culture and the social institutions that maintain it (2003: 112-5). Fiske does not mean to suggest that resistance is futile, on the contrary: "subordinated subcultures exist and intransigently refuse finally to be incorporated people in these subcultures keep devising new ways of tearing their jeans" (115). Just as the meaning of jeans can be appropriated and altered by a resisting segment of society, so too can all ideological output found in the media. This example shows that the production of popular culture is not exclusively top-down/reaching mass popularity from the influence of the elites above.

What is most meaningful in the work of Hall, Morley and Fiske is their commitment to the idea that production of meaning is in the eye of the beholder, and that in the active audience, there is room for resistance. It is important to note that these 
theorists wrote primarily about television media. In Television Culture (1987), Fiske discusses the distinction of public and private when referring to the difference between the entertainment experienced at home via television and an evening out at the cinema (74). He writes: "In going out to the cinema we tend to submit to its terms, to become subject to its discourse, but television comes to us, enters our cultural space, and becomes subject to our discourses" (74). Due to the gory and violent nature of most zombie films, they are exclusively seen in the cinema or on video at home, and are viewed at the viewer's leisure. People watch TV more informally; they have it on while doing other things. Distractions and interruptions abound, especially in the family setting. In contrast, putting on a movie usually prompts a hush of the room and the dimming of lights, directing the focus to the movie and diminishing any distraction. Is this to say that cinema is a more effective medium for conveying ideological messages? Perhaps; or maybe this means that we are more likely to engage critically in entertainment we have actively chosen and sought out. The point is that movies must not be looked upon as a static medium for one-way message transmission. Watching a movie (enjoying one, even) is not to be understood as an act of passive submission to the will of the hegemonic Hollywood elite. The motivations of filmmakers are not necessarily in tandem with dominant mainstream ideology, and even if they are, the audience does not necessarily read them that way. As Jancovich points out, many of the meanings derived from films "are shaped by the range of critical commentary that surrounds them in reviews, articles, star profiles, etc." $(2002 ; 135)$. This is made all the more true with the emergence of the internet as a medium for interactions among critics, fans and anyone else. 
What an active audience does read from movies is difficult to measure empirically. There is not much research done on movie audiences in comparison to other forms of media such as television and radio. Reasons for this, according to Austin, are mostly commercial in nature, as "TV is an advertising-driven medium where the audience is the commodity being sold" (Austen, 1997: 86). Research that enables corporations to make money is more likely to be funded, and film corporations have more interest in ratings and box office figures than the meanings gleaned from the films by the spectators. By virtue of the analyses presented in this paper, one can make an argument that satirical and oppositional elements exist in the films, but whether or not this actually engages critical thought is hard to determine. It is clear, however, that zombie film aficionados have become more than just theatre-mates. Cyberspace has been fertile ground for zombie fans to communicate. Amid the zombie art and comics, zombie fan fiction and zombie survival guides online, there are forums in which fans can participate in a discussion of what they would do in the event of a zombie invasion: where they would hide, how they would arm themselves, etc. In addition, zombie fans in various cities have mobilized an annual "Zombie Walk," in which participants dress like the undead and stagger through the streets (and often a shopping centre) en masse. The first zombie walk was in Sacramento, California in 2001 to promote a local midnight film festival. Since then, walks have occurred in several cities in Canada and the U.S. In Ottawa, the Zombie Walk begins at the gates of a cemetery (not inside the actual cemetery; to do so would be considered disrespectful to the actually deceased dead) and marches along the downtown core and through a major shopping centre. Wikipedia.org contains useful statistics and a directory of Zombie Walks in numerous metropolitan 
areas around the world, including Brisbane, Helsinki and São Paulo, Brazil. The purpose of such walks varies by participant; some walk for fun, others to recreate the irony of brainless mobs stumbling through malls, as depicted in Dawn of the Dead (1978). Some even include a philanthropic component, such as raising money for charity or a blood drive. The site for the Ottawa Zombie Walk did not contain much information about motivation; it claims the walk "is just mindless fun" (- pun intended, I imagine) (www.zombiewalk2005.tk). The Orlando Weekly described the Florida Zombie Walk as a "moaning, groaning experiment in guerrilla theatre [which] can be traced to the most elemental of motivations - i.e., getting a reaction, any reaction" (orlandoweekly.com/calendar/event.asp?whatid $=65975$ ). While this allegation makes zombie walkers out to be attention-seeking adolescents rather than critical thinkers, it remains clear that there is more to zombie movies than mindless entertainment; George A. Romero's Dead series has literally gotten people on their feet.

This chapter has endeavored to introduce the main concepts that will be used throughout this paper to analyze ideological content in George A Romero's Dead series. Having established cultural materialism as an analytical standpoint in which culture is defined by a push/pull relationship between culture as depicted and culture as lived, one can apply cultural materialism to a body of text in an attempt to contextualize its content with reference to contemporary social conditions. Cultural materialism argues for the complexity of the relationship between culture as it is lived and culture as it is manifested in literature, and argues that the two influence each other in a constant, hegemonic struggle of representation, opposition and incorporation. As we shall see in subsequent chapters, Romero's Dead series tackles subjects of community, race, gender, class, 
military power, consumerism and the supremacy of science, all of which can and may function to challenge and subvert dominant understandings. Williams writes that oppositional cultural forms are significant because "They contribute to the effective dominant culture and are a central articulation of it. They embody residual meanings and values, not all of which are incorporated, though many are. They also express emergent practices and meanings, yet some of these may eventually be incorporated, as they reach people and begin to move them" (1980: 45). As a method, cultural materialism is best suited to analyze the emergent oppositional themes apparent in Romero's Dead series, because it locates the films in the modern Western culture, replete with elements of consumerism, consumption and containment. The following chapters will isolate the ideological features inherent in the figure of the zombie itself, followed by an in-depth textual analysis of each film, isolating relevant cultural elements and discussing how they both describe and challenge dominant Western ideology. It will be argued overall that these films are able to inspire critical thought among an active audience, and have mobilized emergent, oppositional culture. 


\section{Chapter 2 - Night of the Living Dead}

\section{I - A Haitian Zombie in Hollywood}

The previous chapter sought to introduce and explain the important links between culture as it is lived and culture as it is represented in film. This chapter seeks to isolate and describe the significance of the zombie as a monstrous product of Western fears and apprehensions. The figure of the zombie as it appears in Western horror film is socially significant for three main reasons. First is the context of its "discovery" in Haiti. The original Haitian Vodoun zombies were discovered in the context of colonialism and were defined within discourses of savagery. These themes reappear in George A Romero's Night of the Living Dead. Second and equally important are the alterations made to the zombified character as it appeared in George A. Romero's Dead series. These differences reflect dominant Western ideology in decidedly unflattering ways, with reference to a Western legacy of imperialism, occupation and persistent racism. Third, movies featuring the Americanized zombie contain strong satirical elements, making subtle yet poignant critiques of Western culture. This chapter will elaborate the historical and contemporary relevance of the zombie before moving on to a discussion on the zombie as it appears in American horror film today.

Contrary to popular belief, the Western myth of the mindless, flesh-eating zombie was inspired by actual recorded accounts of human beings rising from the grave. In 1982, Canadian ethnobotanist Wade Davis traveled to Haiti to investigate such claims (Davis, 1988:1). The story of Clairvius Narcisse reached Harvard University in 1980. Narcisse, it was reported, was found wandering around his village a full eighteen years after being declared dead and buried (1988: 80). Physicians (American as well as Haitian) verified 
his identity via interview and fingerprint analysis (80). The Botany department at Harvard hypothesized that a toxin of some sort must have been used, one which produces a deathlike state, which could be remedied at a later time by an antidote (83). Davis writes, "Theoretically, at least, it was completely conceivable that a drug might exist which, if administered in proper dosage and in some tenable manner, would lower the metabolic state of the victim to such a level that he or she might be considered dead. In fact, however, the victim would remain alive and an antidote, properly administered, could then restore him at an appropriate time" (83). Such a drug could be useful to modern medicine in the field of anesthesia, so Davis himself traveled to Haiti to determine the components of this mysterious drug and the truth behind the mythical Haitian zombie.

Davis identifies the term zombie as it derived from the Kongo word nzambi meaning 'spirit of a dead person', because this meaning appeared to be most consistent with the way in which the Haitian Vodoun themselves understood it (57). The chemical compound turned out to be made up of one part neurotoxin and two parts superstition. The active pharmacological ingredient was tetrodotoxin, an extremely potent poison found in the Tetreodontiforms order of marine fish. This is the same species of blowfish often consumed (carefully, and with much bravado) as a delicacy in Japan, and it is among the most poisonous substances known. Tetrodotoxin affects the normal functioning of nerves and muscles, temporarily causing complete neuromuscular paralysis. This poison is mixed with culturally symbolic ingredients, such as human remains (eg - shavings of skulls and bones) and skin irritants (like ground glass) to cause the victim to scratch itself, thus inflicting wounds for the poison to penetrate further. It is 
then ritualistically administered to the intended victim's front doorstep in the middle of the night. The victim would presumably walk over it the following morning, absorbing the poison through the soles of their feet (146).

To the Vodoun, zombification has far more to do with the soul than the body. The poisonous powder is made by the village bokor, who practices black magic and sorcery for a living (4). Describing the process, Davis writes, "The bokor gains power by capturing the victim's $t i$ bon ange, that component of the Vodoun soul that creates personality, character and willpower. A zombie appears cataleptic precisely because he has no $t i$ bon ange. Robbed of the soul, the body is but an empty vessel subject to the commands of an alien force, the one who maintains control of the $t i$ bon ange" (213). After the victim is declared dead and buried, the bokor has the body exhumed; the victim (now a zombie, and a slave to whoever is in possession of their ti bon ange) is often brought to farms or plantations to labour without pay (9). The victim's $t i$ bon ange is stored by the bokor in a jar; the zombie can be 'freed' by the release of its $t i$ bon ange, or the death of the bokor. (60)

In order to hire a bokor for zombification services, one must first present one's case to the Bizango secret society and demonstrate that such heinous punishment is appropriate; the Bizango then conduct their own juridical trial. Davis writes, "Those who are taken in the night by the Bizango society are not innocent victims but those who have committed some antisocial offense." Davis provides a list of the seven worst offenses to the Vodoun community, ranging from transgressions of attitude ("Displaying lack of respect for one's fellows"), to indiscretions ("Stealing another man's woman"), and blasphemy ("Denigrating the Bizango society") (276-8). Narcisse believed that he had 
been turned into a zombie because of a land dispute between himself and his brother (80) Land disputes between family members are especially frowned upon in the Vodoun community. Thus, zombification was originally a form of punishment: social sanctioning decided unanimously by the Vodoun community.

Here we encounter a crucial difference between the Haitian Vodoun zombie and its Americanized flesh-eating counterpart. The concept of one's ti bon ange, or soul being under the control of an outside being is what is terrifying for the Vodoun (57). "In Haiti, the zombie sits on the cusp of death and the beliefs that mediate the phenomenon are rooted in the very heart of the peasant's being. The existence of zombies is but a confirmation of a fundamental conviction that the dead wield power in the world of the living" (57-58). Most important for purposes of this paper is the fact that the Haitian Vodoun do not fear being harmed by zombies; they only fear becoming one (213). This is a significant distinction from the fictional Americanized zombie, who presents an actual bodily threat to anyone within arm's reach. Behaving according to existing social norms will protect a Haitian Vodoun from harm, but no one is safe from the American undead. The implications of this difference are twofold: themes of culpability and cultural consumption.

The first difference between the Haitian Vodoun zombie and the Americanized horror movie zombie is the question of a zombie deserving its undead fate. While the Vodoun may well pity a zombie, their living dead are believed to be serving a harsh sentence for violating community norms. Their plight is terrible and terrifying, but it is understood that they have made their proverbial bed. In contemporary American horror 
movies, the zombie epidemic does not differentiate between the guilty and the innocent. ${ }^{1}$ Many of these movies feature infant and child zombies; even clergy can be infected.

Some films also feature undead birds and animals. That the zombie infection is a threat to everyone and not just to the deserving suggests that the entire population being attacked is culpable, on a cultural and not individual scale. In the case of the West, globalization processes have reached a momentum where Westerners realize that their everyday actions have destructive and far-reaching implications. Does your engagement ring have a blood diamond? Were your running shoes made by 10 -year-olds in China? It has become common knowledge that in comparison to the rest of the world, Western life is one of gluttony and greed in the name of hedonism. In the case of the Vodoun, the guilty party is determined in isolation. The implication that the Western population under siege deserves its undead fate is a theme to which I will return below.

Another interesting dissimilarity between the Haitian Vodoun zombie and its Americanized counterpart is the addition of consumption and contagion to the latter. Allegations of cannibalism, disease or more general 'impurity' (biological, moral) have been employed to justify exclusion and subjugation of minority groups in the West. It is telling that in Western horror movies, this originally Haitian condition 'infects' the West via flesh-eating; the cannibal taboo is also rooted in Western imperialism. Historically, the practice of cannibalism has been attributed to indigenous populations that came under European colonial invasion in the $15^{\text {th }}$ century, such as the Carib tribes in the West Indies and South America. Many post-colonial scholars contest the accuracy of the allegations of cannibalism collected from journals of explorers in colonial times; as the colonization

\footnotetext{
${ }^{1}$ Reverend Hicks is an exception in the $30^{\text {th }}$ anniversary edition of Night of the Living Dead, who manages to escape undeath despite being bitten, presumably due to his faith: discussed further in next section.
} 
effort was largely based on ethnocentric and racist ideology, retrospective study of these accounts suggest that they may have been exaggerated by the colonizers to justify 'civilizing' efforts of the 'savage' other (Hulme 1998; Obeyesekere 2005; Petrinovich 2000). The cannibal 'trait' began as a homogenous characteristic of the monstrous racial 'other' and now persists in contemporary fiction as a metaphor for cultural practices of the West.

Western imperial practices continue in the $20^{\text {th }}$ and $21^{\text {st }}$ century in a changed context; the figure of the cannibal re-emerges in the industrial revolution, not as the racialized 'other', but as an allegory for the exploitative nature of capitalism. According to the Marxist critique of capitalism, the economic system necessarily involves one party benefiting financially through the exploitation of another. Marx examined the selfdestructive characteristics of capitalism and predicted the eventuality of a decimated population due to ravenous Bourgeois greed: he wrote about the vampiric tendencies of capital, with the metaphor of the dead sucking the blood from the living (1970: 342). Phillips writes, "Marx imagined capitalism as cannibalism with two ends in mind: to emphasize the sheer brutality of the profit-motive as a measure of human affairs, and to emphasize the profound irrationality of a system that must perforce devour itself" (1998: 185). Reduced to commodities, human beings become objects to be used for the benefit of another; or, to put it another way, people become fuel, or food. As the cannibal has been constructed as a selfish, savage being who survives at the expense of the life of another, it becomes an allegory for the Western consumer. The suffering and death of another human is necessary for the satisfaction of the cannibal's hunger, just as the accumulation of wealth requires capital to drain life from workers. 
In the post-industrial context, the metaphor of the cannibal is still relevant to describe the globalized social reality: the entire Western continent as global cannibal and consumer, preying on the poverty of non-Western nations. Processes of globalization and free trade posited the West as a cannibal, impoverishing and feeding on non-Western populations, exploited by powerful and largely unregulated transnational corporations (Bartolovich, 1998: 216). The language surrounding Western consumption resonates with colonial cannibal discourse; the West "leeches" wealth and labour for non-Western countries, global commerce is a "dog-eat-dog" world, etc. As we have seen, historical discourse of the figure of the cannibal posits it as a being outside humanity, which feeds to meet its own hunger at the expense of its own kind. Eating is unique among other material forms of consumption in that it is especially selfish. When one eats something, one is only seeking to benefit oneself; thus, the consuming the flesh of another is the ultimate parasitic behavior.

What is especially interesting about the cannibal is that its monstrosity is redefined to fit changing social circumstances. We have discussed the colonial/cannibal with reference to the social conditions of imperialism, discourses of racism and civilization. At this time, the cannibal was posited as an animal-like creature, beneath humanity. In the contemporary context, the consumer/cannibal is constructed as beyond humanity; a superhuman enterprise of consumption and devastation. The colonial/cannibal was supposed to have eaten human flesh because of its proximity to nature and primitive ignorance. The consumer/cannibal is malicious and bloodthirsty; eating only to consume a hunger that is never satisfied. Thus, the cannibal is consistently 
used as a metaphor for the individualist human that preys on fellow humans: a most abhorred threat to social order.

The zombies that appear in Romero's dead series are an amalgamation of colonial discourses of savagery, racism and cannibalism. Thus, it seems appropriate that Romero's cinematic visions of Western zombie invasions are loaded with satirical themes, criticizing racism, individualism, consumerism and other American legacies. It is interesting that in Romero's films zombies only partially consume their victims, which suggests that the inclusion of the cannibalistic flesh-eating trait is symbolic rather than literal (Paffenroth, 2006: 4). Prior to Romero's Dead series, zombie movies such as White Zombie (1932) and I Walked with a Zombie (1943) took place in removed environments overseas. Both these films are about white plantation owners living in the Carribean region, and both plotlines involve the turning of a woman into a zombie for the purpose of possessing her in a subservient, mindless state. While the themes of female commodification and domination presented in these films are questionable at best, they do not fit the scope of the purpose of this paper. The zombie films of George A Romero are placed in the Western context, bringing the horror closer to home.

\section{II - Night of the Living Dead; Authority, Racism, Culpability.}

George A. Romero's Dead series includes Night of the Living Dead (1968), Dawn of the Dead (1978), Day of the Dead (1985), Land of the Dead (2006) and Diary of the Dead (2008), all of which were directed by Romero. The 1990 remake of Night of the Living Dead was directed by Tom Savini with Romero re-writing his original screenplay. Romero was not creatively involved in Zack Snyder's remake of Dawn of the Dead 
(2004) or Jeff Broadstreet's Night of the Living Dead 3D (2006), but it is likely that their popularity gave appetite to a new generation of zombie fans, prompting Romero's return for his most recent installments, Land of the Dead (2006) and Diary of the Dead (2008). For clarity's sake, I will refer to the remade movies by director.

The original Night of the Living Dead (NOTLD) was directed by Romero and cowritten by Romero and John A. Russo. Filmed with a meager $\$ 114,000$ budget, the movie's eventual praise as a "classic" saw tremendous home video sales. The film is currently estimated at grossing $\$ 12$ million in the United States and $\$ 30$ million worldwide (http://www.imdb.com/title/tt0063350/business). Following NOTLD's success, the decision to make another was obvious, but it is speculated that Russo and Romero discovered creative differences in their vision of the living dead. Romero would continue the Dead series, while Russo's films retained the titular suffix of Living Dead (http://en.wikipedia.org/wiki/Return of the Living_Dead (film_series)). Russo cowrote the script for The Return of the Living Dead (1985), but sold his rights to the name prior to the release of subsequent sequels, Return of the Living Dead Part II (1988), Return of the Living Dead 3 (1993), Return of the Living Dead: Necropolis (2005) and Return of the Living Dead: Rave from the Grave (2005). The latter two never had a theatrical release, and Russo's films are generally not regarded as having the same cultural integrity as Romero's Dead series. Neither Russo nor Romero had creative involvement with the sequels Children of the Living Dead (2001) and Day of the Dead 2: Contagium (2005). At the time of its original release in 1968, some dismissed Night of the Living Dead for its profuse gore. However, many praised the social commentary inherent in the story of several strangers trapped in a country farmhouse by the living 
dead. This portion will begin with a synopsis of the original film, and will continue into textual analysis and end with a look at Russo's 1999 amendments to the $30^{\text {th }}$ anniversary edition DVD.

Kendall Phillips credits much of NOTLD's oppositional themes to the shift from the hippie optimism of the 1960 s to a growing sense of fatalism that pervaded the 1970 s, fueled by the specter of nuclear war and by the assassinations of promising progressive leaders such as Martin Luther King Jr. and Robert Kennedy (2005: 86-88). Having been released in 1968 on the cusp of the two decades, NOTLD both underscores the political climate of the late $60 \mathrm{~s}$ while predicting that of the $70 \mathrm{~s}$ : where the resignation of president Nixon brought about widespread malaise and distrust in political authority figures. Night of the Living Dead's most significant contribution to the horror movie genre is in its focus on the human activity in danger rather than the monsters themselves. The audience is only granted a limited understanding of the nature of the threat, which speaks to the terror and uncertainty of the Cold war years. In fact, the word 'zombie' is never once uttered in this film, nor is the term in Romero's subsequent two installments. What is clear from the onset is that they are dead people who have been partially reanimated to attack the living. The group that takes refuge in the house gains further information about the onslaught through its experiences throughout the ordeal, as well as media reports on the radio and television, much of which is speculative and unhelpful. The audience is not privy to any information the movie characters don't have, which engenders their ability to relate to the characters; the audience is made to share their confusion and disbelief as well as their terror. Initially, the news describes the undead atrocity as "those who have recently died" committing "acts of mass murder" and "homicide." The impulse to 
continue to use such real, legal terms to describe the actions of such surreal beings as zombies is suggestive of the media's attempt to provide humanity with a rationalized description of unfolding events.

The film begins with Johnny and Barbra visiting their father's grave out of town. An American flag in the graveyard features prominently in the opening scene, reminding the Western viewer that the horrors in the film take place nearby. Johnny complains continually about the long drive there and the pointless ritual of visiting a gravesite. When Barbra chastises him for being disrespectful of the sacred site, and for teasing her for being afraid of graveyards he mocks, "I haven't seen you in Church lately." The two see a strange man staggering about, whom they initially dismiss as another visitor. When the man gets closer and attacks Barbra, Johnny grapples with the man but is overcome. He falls and knocks himself unconscious on a nearby tombstone. This opening scene contains the first suggestion of culpability; Johnny mocks any notion of reverence for the dead, and is the first victim of zombie assault while Barbra, who reprimanded him, survives. This is a common theme of 'slasher' horror films. Johnny 'deserves' his death because of his lack of reverence for the graveyard and his mockery of Barbra's discomfort. 'Slasher' films often begin with the murder of reckless teens doing something forbidden; teens smoking pot in the park or making out in a parked car set the stage for the violence that will follow. The fact that these initial victims are somehow 'misbehaving' desensitizes us to their murder by distancing them from the main protagonists, the innocent, with whom we are meant to sympathize. In addition to being a common theme of slasher movies, the fact that characters that show deviant beliefs or behavior are often among the first ones killed contains an ideological element. This is an 
example of Hall's dominant/hegemonic code of reading; violations of cultural norms are violently punished, reinforcing those norms. However, as we will see later, no character in NOTLD is considered innocent enough to escape the living dead.

The zombie continues to chase Barbra, who finds refuge in an old country house nearby. She immediately arms herself with a kitchen knife and proceeds to investigate her surroundings. She finds a decomposing corpse on the upstairs landing, and is frightened by the house's trophy room which contains several animal heads mounted on the wall. When she tries to leave the house, she is surrounded by several zombies milling around outside. She is rescued by Ben who is just arriving at the house. He is gentle and reassuring to Barbra, who initially does not respond to him, presumably due to being intimidated by his show of brutality, pummeling the zombies with lead pipes. Once safely inside, Ben and Barbra share their personal stories, but their tales are limited to where they were at the time of the undead onslaught, what they were doing and how they survived. This is the case with every character in the film; their personage and temperament are revealed only by their interaction with other humans throughout the crisis, implying that what life they led before is now unimportant. As they talk, Ben is breaking furniture to barricade the door while Barbra wanders about the house listlessly. He shows confusion and fear, but also acceptance and resolve. He begins proposing courses of action, speaking to Barbra using the pronoun 'we'; i.e. "We need to get where there are some other people." Barbra begins screaming "I don't know what's happening," even though Ben did not ask her for an explanation. She becomes hysterical when Ben refuses to go look for Johnny, and she slaps his face. In a moment of anguished 
frustration, he hits her back hard enough to knock her out for a short while. He then lays her gently on the couch.

The relationship between Ben and Barbra has been the subject of criticism and debate due to the assumed power relations inherent in her status as a white woman, and his as a black man. Romero and Russo both maintain that Ben's race was not determined at the writing stage, and Ben's role was simply given to the actor who gave the best audition (quoted in Jones, 2005: 118). Despite this disclaimer, it is significant that the central hero of the film is a member of a racialized minority in Western culture. Ben's racial difference from the rest of the characters is highlighted by other unique qualities: apart from his being the only non-white member of the group, he is clearly the largest physically, and the calmest. He naturally assumes a leadership role over the other inhabitants of the house (Barbra, Tom, Judy, Harry and Helen) almost immediately. He is the only human character in the film to overpower another physically: be it a zombie or a fellow human. He is also a moral authority, protective of Barbra in her hypnotic state, and admonishing Harry for his selfishness and unwillingness to help. As active audience theory would argue, Ben's blackness can be interpreted in a variety of ways depending on the viewer. Ben's racial segregation combined with the fact that only he is able to cope effectively with the crisis suggests a link between his race and his coping abilities. In an oppositional reading, it could be argued that the character of Ben seeks to challenge the continuing misrepresentation of blacks in North American media as inherently criminal, or immoral. In a dominant/hegemonic reading, it could be suspected that Ben's coping abilities in such a violent context are indicative of an innate understanding of savagery and brutality, harkening back to aforementioned discourses of race and cannibalism. 
Ben finds a radio and a hunting rifle in the closet. He turns on the radio and listens to news reports giving "...the facts as we know them" about the undead rising. The onslaught is being described as "acts of mass murder" or "homicide." There is limited information on the assailants; they are described as either "ordinary-looking people," people "in a trance," or somewhat "misshapen"; characters refer to the monsters as "them" or "those things." Barbra awakens, but remains catatonic for the bulk of the film. Ben attempts to comfort her by sharing the knowledge he has gained and the good fortune of their available resources, but she remains unresponsive.

Then Tom and Harry suddenly emerge from the cellar, startling Barbra and Ben. They were drawn by the sound of the radio. An argument breaks out between Ben and Harry as Ben reprimands Harry for hiding in the basement and not making his presence known to help Ben and Barbra secure the house. Initially, Harry claims not to have known they were upstairs, despite Ben pointing out that he should have heard Barbra's screams. Beaten, Harry admits that he feels that the cellar is the safest place in the house and that he wouldn't open the door and compromise his own safety “just because someone needs help". Tom explains to Ben that Harry has a wife and injured daughter with him downstairs, as if partially to excuse his hostility and selfishness. The argument culminates with Harry suggesting that they should all take the radio and hide in the cellar. Ben refuses, countering that the house has been secured (no thanks to Harry et al) and that the dead-end cellar should be considered a last resort. When Harry says he will not open the door for them later and tries to take Barbra downstairs with him, Ben tells him, "Go down to the cellar. You can be the boss down there. I'm the boss up here." Tom, sensing Ben's capabilities, calls for his girlfriend, Judy, to come up from the cellar. Harry 
retreats to the basement where we meet Helen, Harry's wife and their daughter Karen. Karen is lying down and moaning in pain; we later learn she has been bitten. Harry rants that the others will regret not listening to him, and his wife placates him. In the end, Harry decides to stay where the gun and radio are kept, and he and his wife come upstairs.

Harry represents Ben's only real adversary as unspoken leader of the group. Ben's character epitomizes a morality of collectivism and co-operation, while Harry behaves in accordance with Western dominant principles of individualism and self-interest. Ben and Harry argue about whether the group is safer in the cellar. Harry maintains that the cellar is safest, but Ben argues that it should only be used as a last resort if the security of the main floor of the house is breached. When they cannot agree, Harry threatens to take the radio into the cellar with him, and states that he will refuse to open the door to them later. Here, Ben and Harry have reached a stalemate; should they agree to separate, Ben loses access to the cellar. On the other hand, Ben controls the gun and the radio. The other house members must choose between security in the form of being trapped (Harry) and freedom to media technology and weaponry (Ben). The audience is made to sympathize with Ben, who had already demonstrated natural leadership abilities and exposed the contradictions in Harry's claims not to have heard people upstairs. It is only when the argument culminates in a potentially physical altercation that Harry relents and agrees to help defend the main floor. Ben is able to intimidate Harry physically, as he is much larger and evidently stronger than Harry. Harry's panic as well as his business suit and tie stand in contradistinction to Ben's casual calm, further emphasizing their class and racial difference. 
Ben devises a plan for the group to escape the house, which involves Harry securing the front door and dropping Molotov cocktails from the second floor window onto the zombies below while Ben and Tom refuel Ben's truck. Judy refuses to let Tom go alone, and her foolish interference results in the destruction of the truck and both Tom and Judy's death. When Ben tries to get back into the house, Harry refuses to let him in. Ben eventually forces his way in and beats Harry. Harry takes his beating almost dutifully, neglecting to fight back or even defend himself. As they fight, zombies break in to the house and Harry takes advantage of the chaos by getting hold of the gun and turning it on Ben. Ben is able to wrestle it away and shoot Harry in the gut. He stumbles down to the cellar and dies reaching for his unconscious daughter. Meanwhile, upstairs, Barbra breaks her catatonia to help Ben and Helen fight off the groping hands penetrating the broken windows. When Barbra is attacked by an undead Johnny, she is unable (or unwilling) to fight him off. Helen retreats to the cellar to find her now-zombified daughter eating her dead husband's arm. She is too horrified to move and Karen stabs her to death with a garden spade.

Feminists have criticized the way women were portrayed in the movie, and reasonably so. Following the zombie onslaught, Barbra goes from hysterics to nearcatatonia, and contributes little to helping the group survive. In the DVD commentary, co-writer John A. Russo remarks that actress Judith O'Dea "brought a tremendous energy; you believe she's terrified" (Russo, 1999), which strikes one as bizarre when Barbra is consistently stunned and dumb. Barbra is the only character to decline into denial, suggesting that she hasn't the strength to bear the situation. The other women, Helen and Judy, are completely dependent on their husband and boyfriend respectively, 
and thus retain some will to survive. Without Johnny, Barbra is useless. Ironically, it is zombified Johnny who overwhelms and devours her. In addition, we find Barbra staring longingly at a music box with a ballerina and clutching at a lace tablecloth; it is almost as if she clings to the comforts of femininity and domesticity. The character of Judy is equally unhelpful to the group, as her inability to control her terror is ultimately the cause of her and Tom's death and the destruction of the precious escape truck. Helen cares for her wounded daughter, and patronizes her husband when he complains that no one is listening to him. When Karen dies and reanimates as a zombie, Helen is unable (or unwilling) to fight her off; crying "My baby... my baby..." while getting bludgeoned to death. This consistent depiction of women as physically and mentally weak is an unfortunate example of sexism that is consistent with dominant Western stereotypes of femininity. It is interesting as well as disappointing that the film challenges racist conceptions while adhering to sexist ones.

Having survived the night alone in the cellar, Ben hears shooting outside: a group of local (white) men are combing the community shooting zombies. Even though Ben is cautiously approaching the window with his rifle cocked, the men mistake him for a zombie and shoot him in the head. The film ends with a black-and-white photograph of the posse burning the corpses, with Ben's among them. His death is shocking; for Ben to have survived the night alone and have a search and rescue party so nearby, he is assumed to be saved at last. Once again, his race is highlighted by his execution as a black man being shot without hesitation by a group of white rednecks. His death is the ultimate ominous ending to the film suggesting that doom is inevitable, and that morality, intelligence and physical strength do not count for much in a racist social context. 


\section{III - Romero vs. Russo; the $30^{\text {th }}$ Anniversary Edition}

Despite the success of the collaborative efforts of Romero and Russo, it is suspected that there was bad blood between the former partners. The $30^{\text {th }}$ anniversary edition of the Night of the Living Dead was released on DVD in 1999. In this special edition, co-writer John Russo included his own version of the film with additional scenes and a changed musical score. It is rumored that Romero was not involved in this retooling due to creative differences with Russo, which will be discussed more fully momentarily. Russo is credited as the sole writer and director of the $30^{\text {th }}$ anniversary edition, despite the fact that the additional scenes he added to the original film only amount to an extra 15 minutes. In the commentary, Russo claims to have been the one to come up with the idea that zombies should be cannibals. This claim becomes suspect, however, when the other commentators begin making fun of him, saying that he takes credit for the invention of doilies and tennis shoes as well.

A retrospective look at Russo's later films compared with Romero's reveals differences that are both stylistic and structural. Russo abandoned NOTLD's dark gravity and satire in favor of a more slapstick style film, replete with the horror-movie clichés; toilet humor, teenage sex, and excessive nudity. Every Living Dead sequel explicitly explains the zombie apocalypse as the accidental release of "Trioxin" gas, which reanimates the dead. Romero, on the other hand, chooses not to explain the origin of the undead rising, in favor of focusing on the human interaction in the aftermath. Another marked difference between Russo's and Romero's sequels is the characteristics of the zombies themselves; Russo's Trioxin-infected dead are able to articulate their hunger for human brains verbally, and often comically. Romero's moaning undead are less 
discriminating; their hunger is for human flesh in general, and not brain matter specifically. They are unable to communicate, although the plotlines of Romero's Day of the Dead and Land of the Dead suggest the possibility of the undead being able to learn, to remember and even to organize. Finally, Romero's zombie apocalypse afflicts only the recently deceased; those who have died after, during and shortly before the outbreak and are unburied, and of course, the direct victims of zombies. Trioxin, as per Russo's remakes, is able to penetrate the earth, enabling the buried dead also to rise and somehow to exhume themselves from the grave.

In the audio commentary of the anniversary edition of Night of the Living Dead, Russo appears to anticipate a backlash from fans for his new additions by stressing that the extra work was done with the utmost respect and reverence for the original film. He describes the great pains that were taken to 'match' the new scenes with the original footage in terms of picture quality, car models, and other props (Russo, 1999). Despite these efforts, his added scenes distinguish themselves from the rest of the film due to the fact that the dialogue in these scenes was poorly written, and the performances almost painful to watch. Despite their shortness relative to the entire film and despite Russo's claim that they were only meant to add a little "backstory," they affect the overall tone of the movie in significant ways.

At the very beginning, Russo adds a scene in which two young men are transporting a coffin containing a recently executed rapist/murderer to the graveyard. When they get there, a man and woman (friends/relatives of the murdered girl, or possibly parents?) and a clergyman are present for the murderer's burial. When the priest begins the usual funeral prayer, the man and woman leave in disgust, claiming "He 
doesn't deserve a prayer." As the young men begin digging the grave, the corpse in the coffin reanimates and becomes the same zombie who attacks Barbra and Johnny in the same graveyard in the original film. What this new scene accomplishes, if anything, is an unnecessarily overt presentation of one of the main themes in the film. We now know that this initial zombie is a convicted rapist and murderer, suggesting that he was malevolent in life as well as in undeath. Do we (humanity/the innocent) deserve his wrath for failing to dignify his corpse with a proper funeral? The rapist/murderer zombie is an obviously deserving villain, but we are left to wonder if the zombified men, women and children seen later in the film also deserve their fate.

Russo's anniversary edition features an epilogue, wherein humanity appears to have recovered from the zombie holocaust. In his version, Rev. Hicks gets bitten in the face by a zombie, despite his attempts to defend himself by citing scripture. In the epilogue, a reporter goes to interview him and why he thinks he was able to resist transformation into a zombie. He insists that it was because he was rescued by a local elderly couple who bathed him in holy water and prayed for him for "seven days and nights." He claims the living dead were "demons, creatures of Satan" that scientists ("all atheists and agnostics") could not understand in their "pitiful secular rationalizations." $\mathrm{He}$ begins ranting about how all sinners must repent, lest the "dead rise again, possessed by demons." The reporter becomes nervous and leaves him raving. Russo also retooled the radio and television emissions through which the group gained knowledge about the zombie onslaught. Russo's additions featured reporters interviewing more 'specialists' who speculate on the crisis: reflecting Russo's desire to explain the cause of the undead rising, which Romero tends to resist throughout his filmography. 
It is interesting that Russo's five additional scenes are able to change the overall tone of the film in significant ways. The original film ended with a snapshot of Ben's body being burned by the redneck patrol, but the audience is left with some uncertainty as to whether the undead situation is well in hand. Russo's amendment removes this ambiguity, showing a perfectly restored society. Russo's added scenes touch upon the dominant code of individual culpability, but only insofar as Rev. Hicks survived his bite. None of the house inhabitants are blatant "sinners" in a Christian sense, with the possible exception of Harry's failure to help his neighbor. Thus, Russo's amendments serve to obfuscate some of the oppositional elements that made NOTLD such an important film in the first place. In the original film, the group's challenge is to survive one another, not the zombie onslaught. This religious theme is revisited in Romero's next film Dawn of the Dead, which will be discussed in the following chapter.

Kim Paffenroth argues that Tom Savini's 1990 remake of Night of the Living Dead is too similar in plot to the original to warrant separate analysis (2006:2), but like Russo's $30^{\text {th }}$ anniversary edition, even small changes to the same storyline make for large variations in the general mood of the film. The most noteworthy amendment is in the character of Barbra. While equally terrified and traumatized by the death of Johnny, the remake depicts a significantly more resilient Barbra, who eventually overcomes her horrified paralysis and adopts an almost militant air of toughness. Ben and Harry's conflict escalates to a shootout, resulting in Ben being fatally wounded and Harry hiding alone in the house's attic. Barbra makes a run for Johnny's car, promising to send help back for Ben, if she can. She is almost shot by a group of local rednecks who are combing the area. In a theme that will be revisited in the analysis of Dawn of the Dead 
and Land of the Dead, the rednecks appear to be well-organized, and are even enjoying zombie extermination: hanging them from trees as target practice, for example. When Barbra returns to the house with the posse, they find zombified Ben in the cellar, having died from his gunshot wounds overnight. Once left alone, Barbra is startled by Harry who has survived the night in the attic. As he reaches for her, marveling that she's come back for him, she shoots him in the head and tells her team "There's another one for the fire." Savini's retooling of Barbra was consistent with a growing trend of strong female protagonists in horror film since the original NOTLD's 1968 release; the character "Ripley" from Alien (1979) and "Sarah" from Romero's own Day of the Dead (1985) are notable examples. Like Russo's revision, this version of NOTLD shows humanity to be handling the undead rising, albeit crudely. The lingering horror of the film is in a final close-up of Barbra's eyes: highlighting the horror that caused her evolution into a ruthless zombie-slayer.

In any version, it is Night of the Living Dead's focus on humans rather than monsters that sets it apart from other films within the genre. The plot of an undead rising allows for particular constructions of humanity to emerge: a tragic situation in which suspicion and lack of co-operation break down what would have otherwise been a sustainable site for survival. That the film has been recognized for its social significance in the U.S. National Film Registry indicates that dominant cultural agencies recognize its importance. In order for a film to be inducted into the registry, it must be at least ten years old and be "culturally, historically, or aesthetically significant" (quotations in original; National Film Registry, 2008). On its website, the Registry claims to choose films in consultation with "film experts" and registry members and alternates, who are 
composed of such organizations as the Society for Cinema and Media Studies, the Screen Actors Guild, and the Writer's Guild of America. It also welcomes nominations from the public, who can vote on titles, but The Library of Congress gives no concrete definition of what is meant by cultural "importance," nor any justification for its choices (other horror movies making the list include Hitchcock's Psycho [1960] and Ridley Scott's Alien [1979]). This is especially interesting when one considers that upon its release in 1968, the film sparked censorship debates due to the explicitness of the violence depicted. Thus, one wonders if NOTLD's subversive themes are being praised by the U.S. government, or if the government's recognition of this film is evidence of dominant culture incorporating these oppositional elements.

This chapter has sought to introduce the zombie from its origin in Haiti to its redefinition as a contagious undead cannibal in George A. Romero's Dead series. A cultural materialist analysis showed that Romero's first film in the series, Night of the Living Dead, highlights the social construction of the zombie as a monster by putting it up against a desperate group of humans who are unable to cooperate with one another enough to survive. The film's overall suggestion that the Western social context of racism, sexism and individualism is more insidious than the living dead has made NOTLD an enduring horror classic. The next chapter will look at Romero's next two films, Dawn of the Dead and Day of the Dead, with an aim to unpack the satirical themes in these films and pit them against the Western social condition as it is lived and the ways in which they might be understood by a critically active audience. 


\section{Chapter 3 - Dawn of the Dead, Day of the Dead}

\section{I - Dawn of the Dead}

George A. Romero's Dawn of the Dead and Day of the Dead are considered sequels to Night of the Living Dead, even though their narratives follow different characters coping with the undead rising in different circumstances. While NOTLD captures the confusion and panic from the beginning of the invasion to an ominous end, Dawn of the Dead (DawnOTD) begins its plot three weeks into the zombie onslaught. As discussed in the previous chapter, the narratives of these films are stories of what might occur if the circumstances of the movie came to fruition. NOTLD was a story of seven people attempting to survive the zombie onslaught in a country house, while in DawnOTD, the storyline centers on a group which has access to supplies, weapons and transportation, but must defend them against the rest of the surviving population. Thus, like NOTLD, the speculative themes in the film can be extended to any kind of crisis that has society in disarray: any reason for the instatement of martial law, be it civil war, a viral epidemic or a crash in the economy.

As Kim Paffenroth points out, DawnOTD's gaudy Technicolor stands in distinction to NOTLD's black-and-white, drawing attention to the ways in which society has changed since the first film: both technologically as well as socially (2006: 46). Specifically, DawnOTD takes aim at capitalism and the rampant consumerism of the late 70 s. The late 1970 s are marked by a breakdown of the nuclear family and the rise of women's movements, both of which are touched upon in the film. The film also reflects the societal attention being paid to war veterans, and what became known as Post- 
Traumatic Stress Disorder (PTSD) when several soldiers become too carried away in battle, and must be stopped lest they worsen the situation. The emergence of an American culture of consumerism, however, takes the forefront in DawnOTD's line of fire. It is implied throughout the film that when social order breaks down, all the material goods accumulated will count for little: in fact, they are shown to be the cause of deception, competition and further bloodshed.

The film begins with a shot of a young woman, Fran, being roused from a fitful sleep. She is in a chaotic television studio, where reporters and technicians bustle about busily and on set, two men argue about what the zombies are and how to deal with them. The TV show's guest is referred to as "Dr.", but his area of expertise is not given. $\mathrm{He}$ gives a very brief report: "they" are corpses that kill, and the people they kill get up and kill. The TV host is annoyed at his impossible answers, accusing the "experts" of withholding information: "all we know is what 'you people' are telling us." The specialist counters that the population is ignoring the advice given by the experts by refusing to incinerate the bodies of their loved ones, saying that "If we listened, if we'd dealt with this phenomenon properly, without emotion, it wouldn't have come to this." This opening scene of the film already contains a variation on the central theme of Night of the Living Dead. In NOTLD, the general premise is that the undead rising illustrates the inhumanity of the living in the Western social context of individualism. Despite the desperate need to co-operate, the characters cannot help but struggle with one another, which is what ultimately brings about their demise. In DawnOTD, the expert is blaming humanity's inability to distance itself emotionally from the corpses of loved ones in order to avoid attack. On one hand, this can be understood to contradict NOTLD's allegation of 
humanity's cruelty by suggesting that the sentiments of love and empathy are humanity's undoing, rather than the lack thereof. However, subsequent scenes will imply that it is conformity and adherence to tradition that is the cause of people's unwillingness to cope with the crisis rather than emotional attachment.

As Fran learns that the TV station has been airing lists of closed rescue stations, she confronts her supervisor to have them taken off the air. He wants them aired at all times whether they are operative or not: "Without those rescue stations on screen every minute, people won't watch us. They'll tune out." Many staff members leave their stations and walk out in disgust. As they argue, Fran is grabbed by Stephen who tells her to meet him on the roof to escape with him in his helicopter. She is reluctant to abandon the TV station, but a co-worker tells her that the station is being cut off anyway, that their "responsibility is finished." The supervisor's priority is with his ratings rather than the integrity of his role as medium or the safety and continuation of his entire species, setting the stage for the critique of individualism that will resound throughout the film. The implication of untrustworthy media is noteworthy here, as it highlights humanity's inability to cooperate on a macro scale. Despite the fact that all of humanity is at risk, morality and ethics are still being compromised in favor of professional motivations.

Here, the film cuts to a scene in which a military SWAT team is forcibly evacuating a decrepit apartment building. A group of its occupants, led by Martinez, is resisting evacuation. On the rooftop, the siege turns into a bloodbath as overzealous soldiers brutally gun down a group of black and Latin men who emerge from the building. The soldiers work their way down the building through the stairwell, gunning down zombies while trying halfheartedly to rescue uncooperative tenants. Amid the 
chaos two troopers, Roger and Peter, become friends. They discuss the temptation to abandon their duties and "run." Roger reveals that Stephen is coming to pick him up in a helicopter that night and invites Peter to come along. They are interrupted by an old crippled priest who begs them to let him pass so he can find his sister. He tells them that the building's residents have kept their dead in the basement: that he has given them their last rites, and is now willing to give the corpses over to the police. He leaves, saying "When the dead walk señores, we must stop the killing or we lose the war." The basement is teeming with zombies. Peter is barely able to hide his revulsion as he tries single-handedly to destroy the room full of corpses feeding on one another. As Roger helps him, he wonders aloud why these people kept them down here. Peter suggests that they still believe there is respect in dying. This scene touches upon another theme from NOTLD that emerges again in Day of the Dead: that non-whites have an innate understanding and ease with the zombie apocalypse. In NOTLD, Ben is the only one to keep calm at all times, as well as the only one able physically to overpower a zombie face-to-face: as though he is innately more comfortable with savagery and violence. In DawnOTD, Peter is simultaneously a warrior-juggernaut who is able to kill zombies quickly and efficiently, and a philosopher-priest who speculates on the zombie onslaught from a spiritual perspective. This represents two stereotypical attributes often applied to racialized minorities in the West: savagery and superstition.

When Stephen and Fran stop to pick up Roger and Peter and refuel the helicopter, they are almost hijacked by a group of fleeing security guards. They manage to talk their way of out harm, pointing out that the helicopter cab holds so few. As they return to the cabin, one of the security guards desperately asks if any among them has any cigarettes. 
They all say no, but both Fran and Roger light up once the helicopter takes off, showing that they are already aware of the scarcity of resources and showing their unwillingness to share what they have for themselves. Crammed awkwardly into the small cabin, Peter and Fran make conversation. When Peter mentions that he is leaving behind some brothers, Fran asks as whether he means actual blood brothers or "street brothers." He is not offended, despite the obvious racial reasoning for her question. He tells her that he has two real brothers: one of whom is in jail and the other is a "pro ball player," two stereotypical fates for black Americans. He asks her if Stephen is "her man," and she replies with a vague yes. Peter replies with "I just like to know who everybody is," as though her identification as Stephen's "woman" is her defining characteristic. Paffenroth interprets their interaction as indicative of Peter's affection for Fran and desire to diffuse the awkwardness of the situation: emphasizing the fact that his wording implies her ownership of Stephen, and not vice-versa, thus affording her respect (2006: 64). While it is clear that Peter is consistently the most thoughtful of the group (with the exception of the abortion conversation, to be discussed shortly), his desire to establish her romantic availability at the very onset of their meeting reduces her to the token woman of the group. Once again, DawnOTD touches upon Western stereotypes of blacks and women, showing how these social constructions are retained and reconstructed in the direst of circumstances.

Overhead, they pass large squads of local townspeople joining forces with the military to hunt and exterminate zombies. Stephen comments "Those rednecks are probably enjoying the whole thing": indeed, they are listening to loud music, drinking beer and posing for pictures. His remark shows his distain for a lower socioeconomic 
class for its crudeness, despite the fact that those involved appear to be well on top of the zombie threat and are even enjoying themselves. This brief scene is a poignant Marxist commentary on class and class-based reactions to crisis: those with access to expensive transportation segregate and flee, while the less economically powerful come together and make do with what they have. The rednecks' apparent ability to co-operate and share resources stands in contrast to the haughty helicopter-passengers, who look down on them from above and refuse to share their cigarettes.

When they land the helicopter to refuel, the group disembarks and explores its surroundings. At one point, a zombie appears in the doorway between Peter and Stephen. Stephen raises his rifle to shoot it, but he barely misses shooting Peter: Roger intervenes and kills the zombie easily. Enraged, Peter knocks Stephen down and sticks his gun in his face, pointing out how scary it is to have a barrel of a gun pointed at you. Stephen looks terrified and emasculated at being reprimanded in front of Fran, which occurs frequently throughout the film. Peter helps Stephen to his feet and they get back on board the helicopter. In NOTLD, the character Harry was especially confrontational and difficult, and he often explained his selfish behavior by the fact that he had a wife and daughter to protect. By placing his wife and daughter above the rest of the group, he contributed to the rupture in cohesion that brought about the demise of the entire group. In Stephen's case, the theme of dependency is inverted; it is not his protectiveness of Fran that is his failing, but his need to maintain an air of courage and masculinity in front of her. Just as NOTLD sought to show the detrimental nature of individuality and of placing the value of one human life before another, DayOTD demonstrates the primacy of the ego and the need to maintain the illusion of masculinity, bravery and control. 
They land on the roof of a sprawling suburban shopping mall. As they look into the skylights, they see zombies milling around inside and that the stores are gated shut. Roger and Peter quickly team up and break into the mall as if in a military tactical operation. Fran wonders aloud why zombies would come to the mall and Stephen speculates that it may be out of memory, that the mall was an important place in their lives. The idea that zombies are able to retain memories from before their undeath is not suggested in NOTLD, but is explored much more fully in the next installment, Day of the Dead. They find a small storage floor stocked with cartons of canned food and other emergency supplies. There is a stairway leading from the storage rooms into the mall, which they seal off with cartons. While Stephen sleeps, Roger and Peter descend into the mall for supplies. They arrive at the main office where they find the keys to every store in the mall. A montage depicts zombies stumbling along escalators, pawing at the coins at the bottom of a fountain, pushing around shopping carts: overall, the montage is more comical than frightening. Roger and Peter gain entry to a department store and excitedly load supplies into a wheelbarrow. At one point, Peter reminds Roger to stick to what they really need: a TV and a radio. Roger adds lighter fluid and chocolate to the list, to which Peter agrees.

Upstairs, Fran wakes Stephen to tell him what Roger and Peter are doing. He calls them "maniacs" with admiration and leaves Fran alone to follow them. When he finds Peter and Roger, the three work together to get the supplies into the storage bay without leading the zombies to the stairwell: through completion of a successful mission, Stephen gains acceptance as 'one of the guys', when they nickname him "flyboy" and commend him for his help. They return to the storage bay via an elevator shaft to find Fran scarcely 
defending herself against a zombie who came up the stairs. She is very upset, and Stephen soothes her by telling her they have everything they need. As Fran smokes by herself in the next room, Stephen reveals to Peter and Roger that Fran is pregnant. Peter asks Stephen if he wishes an abortion; saying that it is not too late and that he knows how to perform the operation. Stephen hesitates then shakes his head and goes to Fran. Fran has heard everything and is angry that decisions are being made without her. She says she wants to leave the mall: that it has "hypnotized" them, that "it's so bright and neatly wrapped that you don't see that it's a prison too." Stephen, unwilling to side with Fran against his new buddies, argues that fuel is an issue and that national boundaries will be heavily policed. It is important that she uses the term "hypnotized" with reference to the mall. In the first place, it can be said that the manner in which the zombies are stupidly wandering the mall is akin to one who has been hypnotized. But secondly, it draws attention to the manner in which humans wander shopping malls as well: milling about slowly, staring stupidly into shop windows while muzak drones on in the background. It is difficult to identify exactly why Fran wants to leave the shopping mall, if it is because she distrusts the safety of the building or because of the power dynamics she sees emerging. She offers no alternative to their hiding place, because she knows there is nowhere else to go.

The next morning, Fran sarcastically remarks that she would have made them all coffee and breakfast if only she had her pots and pans. She tells them that she does not want to be treated any differently despite the fact that she is pregnant, and that she will not be a "den mother" for them. She wants an equal say in their plans. Then she tells them she wants to learn to fly the helicopter in case anything happens to Stephen and that 
she does not ever want to be left without a gun again. Stephen starts to protest but Peter interjects that this is fair enough, provided she learns to "handle herself," even though she has given no indication that she cannot. Stephen is irritated with her but only because she has voiced concern for his ability to protect her in front of the others. The men embark on a mission to park some large convoy trucks along the perimeter of the mall to keep the zombies away from the glass doors. As they progress on their mission, Roger becomes overly excited and arrogant and Peter must remind him to keep a cool head. When Roger gets increasingly reckless, and Peter loses his temper and grabs him, screaming "you're not just playin' with your life, you're playin' with mine!" Roger hears this and calms down, but he is bitten on the leg shortly thereafter. When Peter suggests that he rest and treat his wound, Roger says they should make good use of him while they can; he knows his time is limited.

The group makes a mission of clearing the entire mall of zombies and locking all the doors from the inside. Roger, unable to walk, shoots zombies from a wheelbarrow. Back upstairs, Fran, Stephen and Peter discuss the long-term sustainability of their makeshift apartment. Roger is sweating feverishly, semi-conscious. Occasionally he calls for Peter, wanting to reminisce on their tactical success as a team. He says repeatedly "We did it, huh, buddy? We whipped 'em!" to which Peter sadly agrees. They decide to seal off the stairwell leading to the storage bay and use only the elevator shaft to get up and down from their hovel. Here, Peter speculates that there might be "a patrol" through there eventually, "looters" perhaps, and they do not want anyone to know they're up there. His comments foreshadow the events that will ruin their safe haven. 
There is a montage of Fran, Peter and Stephen making themselves at home in the mall: Fran playing dress-up in boutiques, Peter browsing a bookstore, Stephen playing pinball machines. As they lean against the top floor balcony, decked out in exquisite leathers and furs, looking down at the zombies pressing themselves up against the outside doors, Fran wonders aloud why they persist in trying to get in. Stephen thinks it's them; the zombies know there are humans in the mall. Peter disagrees, saying it's the mall they want. "They don't know why, they just remember that they want to be in here." $\mathrm{He}$ reveals that his grandfather was a voodoo priest in Trinidad. He recalls that his granddaddy used to tell him that 'When there's no more room in hell the dead will walk the earth'. Peter's spiritual insight to the situation likens the zombies to humanity, while highlighting the difference between his attitude towards the zombies and that of the others.

Peter's remark makes reference to the Vodoun, who were discussed in the previous chapter as the origin of what became the myth of the Americanized zombie. As mentioned, zombification was punishment for social transgressions among the Vodoun community. Peter's grandfather's statement echoes the idea that the dead roaming the earth have come from hell, thus they presumably deserve their fate due to their misdeeds in life. The zombies depicted wandering the mall represent various demographics; there are zombie men, women, elderly, and children. They vary in ethnicity, class and occupation; there is even a zombie nun. John A. Russo's added scenes to NOTLD included a subplot where Rev. Hicks survives a zombie bite due to faith and prayer, but it is clear that Romero does not wish to favor any religious faith with immunity to undeath. Here, the customary cinematic theme of bad things happening to bad people is expanded 
to suggest that our misdoings are on a societal as opposed to an individual scale. Those opposed to capitalist exploitation or occupation in non-Western territories have no choice but to participate in these things in order to survive. Thus, Romero's critique of consumerism includes all who participate in it, both willingly and grudgingly. In Tony Williams' authoritative account of the works of George A. Romero, he writes about a recurring cinematic theme of women becoming gripped by conspicuous consumption and how Romero is novel for featuring men (2003: 86). Indeed, it is Peter, Roger and Stephen who explore the mall excitedly, while Fran wants to leave it from the very onset.

Fran is keeping Roger alive and lucid by injecting him with morphine, but his condition is worsening. He makes Peter promise to "take care" of him when his time comes: "I don’t wanna be walkin' around like that, Peter. Not after I go..." He tells Peter he will try not to come back. Roger is easily the bravest character in Romero's zombie films, as reflected by his utilitarian commitment to continuing to help the group just until his eventual demise and his resolve to try to resist transformation. Again, that such a selfless character is still vulnerable to zombie reanimation reinforces the idea that no one is safe. When Roger does reanimate, Peter shoots him with regret. They bury Roger in a garden in the mall.

Life goes on in the mall: Fran and Stephen spend their time practicing shooting while Peter plays tennis on the roof. They continue to play-shop in the mall, but they appear to be growing bored. Peter, Stephen and Fran eventually set up a lovely apartment, complete with furniture, appliances, paintings and silverware. On the surface, they appear to be settled and content, but Fran, now visibly pregnant, has become depressed. When the TV broadcasts stop, she and Stephen bicker about whether or not to 
leave it on. Now that they are safe and secure, they fight instead of cooperating as they did when they were desperate. It is only when Stephen teaches Fran to fly the helicopter that her depression lifts. Her pleasure is not in the ability to escape should something happen to Stephen: she seems genuinely thrilled to have learned a new skill and to have mastered it.

An enormous biker gang arrives at the mall, noticing the helicopter and the trucks blocking the entrances. The gang uses their radio to threaten Peter, Steven and Fran, saying that they don't like people who "don't share." As they prepare to storm the building, Peter suspects that they will be able to get in to the mall but they decide to defend their makeshift apartment upstairs. The gang uses guns and grenades to get past the zombies in the parking lot and to clear the trucks of the entrances, gaining entry as well as letting in many zombies. Peter and Stephen stay out of sight while the gang loots the mall, stuffing bags with candy, jewelry and silverware. Like the rednecks seen before, they seem to take pleasure exterminating and humiliating zombies by throwing pies in their faces and decapitating them with machetes. Stephen is unable to stand by and watch his home overrun, muttering "It's ours, we took it. It's ours." When he starts shooting at the bikers Peter yells at him to stay out of sight, reminding him, "they're after the place, not us!" This is the second time he has made reference to the value of the mall over that of the living people within it.

Some bikers witness Stephen escaping into the air ducts and try to follow him. Stephen gets shot in the upper arm and stifles a scream. Eventually, the bikers give up and leave; the few that are left behind are graphically devoured by zombies. Stephen is unable to climb into the air duct due to his injured arm, and zombies break in to the 
elevator and bite his dangling legs. When Fran sees Peter return alone, she assumes immediately that Stephen is dead. Peter tells her that he had heard gunshots, and they decide to wait and see if Stephen returns. The reckless and violent biker gang stands in contrast to the well-organized group of rednecks seen earlier in the film in terms of how different classes are reacting to the undead rising. While both the bikers and rednecks appear able to dismiss the emotional attachments that are hindering humanity's ability to cope with the zombies (as mentioned earlier by the expert in the television studio), the rednecks were shown to be cooperating with local police in exterminating the threat, while the bikers show equal disregard for the lives of humans and zombies alike. The difference highlights a misconception of the lower classes that is commonly disseminated by contemporary media in the West: overemphasizing a link between poverty and crime. The key difference between the biker gang and the redneck posse reinforces the point that people are "making do" after the zombie invasion much as they did prior to it: polarizing the bikers' criminal response with the redneck ideology of doing what one can to get by within the boundaries of the law. However, the shocking execution of Ben by some rednecks at the end of Night of the Living Dead calls the effectiveness of their approach into question. Certainly, as demonstrated in all Romero's films, there is no clear "right way" to deal with the zombie onslaught.

The zombies in the mall feast on biker meat as Fran and Peter wait for Stephen all night. By dawn, Fran has given up hope and wants to leave the mall in the helicopter but Peter hesitates. The zombies wander the mall as they did before the group arrived there. Zombified Stephen remembers the wall they put up to block the staircase and leads other zombies to it, who tear it down and start up the steps. Peter tells Fran to flee without him, 
that he does not want to go with her. As Fran goes up the ladder to the roof, Peter stays below and retreats to a back room. He points his gun to his temple, but when the zombies reach his door, he changes his mind and makes for the roof, shooting zombies in his way. Fran has almost taken off in the chopper when she sees Peter and stops to pick him up. He asks how much fuel they have and she tells him "Not much." He says "All right" with a tone of weariness, and zombies watch the helicopter fly away.

This ending is less ominous than NOTLD, where none of the group survives the first night of the zombie onslaught. Fran and Peter have escaped the mall, but the audience is left to wonder what became of them, or of Fran and Stephen's unborn child. Dawn of the Dead can be read as a tale of the best laid plans gone awry. What appears to the ideal hiding place against the undead, replete with food, supplies and weapons, turns out to be as dangerous as the world outside. The film's ending remains unsettling because any speculation as to where they could find safety begs the question: where could they possibly survive if not in a shopping mall with security, food, weapons and resources at their disposal? Paffenroth disagrees: arguing instead for the optimistic implication that anywhere they end up would be better than the insidious shopping mall (2006: 70). DawnOTD is a narrative in which a group thinks it has everything it needs, but comes to realize that abundant material goods are not enough. The group was able to make its makeshift apartment as similar to its previous home as possible but it grew bored and unhappy, feeling trapped by the shopping mall. In addition to not being content there, the group must defend its safe haven against looters who would unflinchingly murder any and all of them for access to their resources. The bikers, still driven by the hegemonic desire for material possessions, steal TVs despite the fact that there are no longer 
television broadcasts. Thus, DawnOTD satirizes the Western emphasis on wealth and material possessions by showing how worthless they are in times of dire need. In fact, they become a point of contention and inter-human conflict, compromising the safety of the entire group.

As with NOTLD, it is difficult to ascertain the dominant/hegemonic reading of this film due to its multilayered satire; the unreflexive viewer will focus on the story without expanding the shortcomings of hiding in the mall to criticize materialism and consumerism. Furthermore, one could argue that the mall was not the problem; the bikers can be blamed, as well as Roger's overzealousness, Stephen's insecurity, and of course, the zombies themselves. It is more difficult to ignore the numerous allusions made to the similarity between humanity and the living dead, from montages of zombies mindlessly wandering the mall (much as we do) and several remarks by the characters (Fran: "What the hell are they?", Peter: "They're us,"). The oppositional reading of both NOTLD and DawnOTD is that the group is essentially doomed from the start due to the current social conditions of American life.

\section{II - Day of the Dead}

By the third installment, Day of the Dead, Romero does not bother to reintroduce the zombie and its characteristics: it is assumed that the audience has a rudimentary understanding of what zombies are, how their condition is spread, and how best to stop one. This demonstrates Romero's awareness of the cult following of his films. The storyline of Day of the Dead (DayOTD) takes place at an indeterminate time after the 
initial zombie invasion, and centers around the idea of how authority is delegated and maintained in this hypothetical crisis. Like DawnOTD, the film's satirical power is in its applicability to a number of different crises which are more likely to occur than an undead rising. It is set in an underground laboratory, where scientists are working with limited means to determine either the cause or cure of the zombie outbreak. They are supposed to be protected by military personnel stationed there, but tensions grow between the scientists and the soldiers as the results they had hoped for do not come and hope starts to wear thin.

Day of the Dead was the least well-received of Romero's Dead series, which Paffenroth credits to a different cinematic style, with much more dialogue and less action than the previous films (2006: 72). Despite the film being "less satisfying" for audiences, she deems the film to be the most complex in commentary of the series, focusing less on social critique in favor of delving into deeper themes of human nature (78). The contrasting occupations of the soldiers and scientists are analogous to their different reactions to the horror and claustrophobia of being shut in from it; the soldiers represent action while the scientists represent reason, and the civilians seek only to live out their lives in relative comfort.

The film opens with its central protagonist, Sarah, sitting alone in a cell-like room. She looks despairingly at a calendar posted on the opposite wall. There is a photo of a cheerful pumpkin patch, which she caresses, until rotten hands reach out of the wall and grab her. She awakens with a start: she was only dreaming. She is in fact on board a helicopter with Miguel, a soldier, who is clutching at a medallion around his neck and praying. John, the helicopter pilot and Billy, the radio technician, sit up front. Sarah 
orders John to land which he does grudgingly. She and Miguel search the seemingly deserted town, looking for surviving humans. A newspaper blows by, and by its headline "THE DEAD WALK!" we learn the town has been overrun by zombies. Sarah and Miguel walk along the empty street in military garb and armed by rifles. Miguel yells "Hello" into a megaphone, but only zombies respond to his shouts. Sufficiently convinced that there is nobody 'living' in the town to rescue, Sarah and Miguel return to the helicopter and they leave.

They arrive at a military camp which is bordered by high fencing and barbed wire. Zombies press against the other side of the fence moaning. When Sarah notices Miguel lagging behind in the helicopter, she goes back for him: he appears to be immobilized with terror. She tries to convince him to take a rest as he is collapsing from "stress" but he gets defensive and bitterly points out that the whole unit is collapsing, except her. As they cross the tarmac, Sarah and John argue; he thinks their work in the military base is pointless, and that they should be spending their remaining days at leisure. As they enter the underground compound, two soldiers, Steele and Rickles, mock them for their failed attempt at finding survivors. When they order Miguel to help them round up some zombies for experimentation, Sarah protests that Miguel is exhausted. Embarrassed, he goes with the soldiers, and Sarah goes with them. Steele and Rickles hoot and holler as they drive along the cave, like teenagers on a joyride while Sarah and Miguel sit on the back in sullen silence. The soldiers have managed to trap a number of zombies in a cave near the compound and have fashioned a gate through which they can safely capture live zombies by luring them toward the gate and isolating them with a trapdoor. The soldiers crudely taunt zombies to lure them toward the gate. As the 
zombies approach, Miguel panics and drops his gun. Sarah takes control of the situation just as Rickles is about to be attacked. Steele becomes enraged with Miguel for his clumsiness, accusing him of almost killing Rickles. He grabs Miguel, and holds his head along the gate such that the medallion around his neck is within reach of the undead below; refusing to let him go until Sarah threatens him with her gun.

Later, in their quarters, Sarah tried to give Miguel a sedative to help him sleep. He is embarrassed by her ability to keep her cool at the gate when he messed up. When she insists on the shot, he slaps her hard in the face twice. When he embraces her to apologize she sticks him in the back with the needle. He weeps miserably, calling her a bitch before collapsing onto his cot. Their relationship is the inverse of Fran and Stephen's from DawnOTD. While Stephen was embarrassed at having to look after his pregnant girlfriend in front of fellow men, Miguel is embarrassed at being protected by his. In the DVD commentary, director George A. Romero jokingly points out that he was, and still is, making amends for the character Barbra's helplessness in Night of the Living Dead.

Sarah enters the mess hall to an argument between Fisher, a fellow scientist and Captain Rhodes. As the argument escalates, Sarah interjects with a plea to get along, pointing out that they need each other. Rhodes disagrees, saying that the scientists in the compound need the soldiers more than the other way around. She goes to the lab and finds Dr. Logan recording oral notes on zombie anatomy and decomposition. $\mathrm{He}$ excitedly tells Sarah that he believes that zombies can be domesticated through Pavlovian reward/punishment conditioning. When she points out that the scientific team is close to losing the cooperation of the soldiers, Logan is confident that they will listen to him when 
they see his results. Then Sarah notices that one of Logan's specimens is wearing a military uniform; the tag identifies the corpse as an officer who died recently. She is disgusted with Logan, who claims "He's helping us more now than he ever did alive."

At dinner, Billy is telling the group that trying to use the radio in the compound is useless, that the frequency is bad and the equipment too old. The soldiers are not listening: they shrug off his complaints. As they get increasingly rowdy and begin sexually harassing Sarah she gets up to leave but Rhodes stops her, threatening her to sit back down or be shot. She stands her ground, not believing that he will do it, but he orders Steele to shoot her on his command. John convinces Sarah to sit. Logan arrives at the meeting and Rhodes starts berating him for his tardiness and threatening to take the soldiers and abandon the scientific team in the cave. Logan refuses to be intimidated; pointing out that they cannot escape the zombie hordes no matter where they go, and that soon he will be able to domesticate the undead. Rhodes reiterates that he is running the show, and if displeased, he'll "pull the plug" on the whole thing. Furthermore, anyone who challenges his command will be shot on the spot.

After the meeting, Sarah tells John that she didn't think Rhodes would have shot her. John points out that he and Billy are only safe from the soldiers because he can pilot the helicopter and Billy is the only radio technician; but that she and the other scientists "better start worrying." When she pleads that they all work together to ease the tensions, Billy and John walk away from her. That night, Sarah has a nightmare of Miguel getting up from his cot and his intestines falling out of his abdomen. She wakes with a start and Miguel is triumphant at finally seeing her scared. He taunts her before ending their relationship and leaving. Later that night, she visits Billy and John who have set up house 
in a trailer deep in the cave. The trailer is cozy and comforting, albeit obviously false: a far cry from the institutional brick and fluorescent lighting of the compound. John is sitting on a makeshift back patio, where a large poster of a beach lines the cave wall, and patio lights and chairs lend an air of vacationing in the tropics. Sarah points out that neither John nor Billy lift a finger to help the scientists or the soldiers, and that she cannot understand how he can pretend nothing is happening. John tells her that all the experimentation and record-keeping is useless when there is no one around to read it. He insists that their attempts toward an explanation are pointless: "You ain't never going to figure it out. Just like they never figured out why the stars are where they're at. It ain't mankind's job to figure that stuff out. So what you're doin is a waste of time, Sarah. And time is all we got left, y'know." When Sarah argues that there is nothing else humanity can do with itself, he suggests that they flee the compound and "start fresh"; hinting at an attempt to repopulate the world. He says "We been punished by the creator. He visited a curse on us so we could look at what hell was like. Maybe he didn't want to see us blow ourselves up and put a big hole in his sky. Maybe he just wanted to show us he was still the boss-man. Maybe he figure we was getting too big for our britches trying to figure his shit out." John is DayOTD's reminiscent of Ben from NOTLD and DawnOTD's Peter as the token black male who is oddly at ease with the undead rising, staying calm and collected while offering spiritual and philosophical insights. Where John differs is that he is not as physically impressive, courageous or violent as Ben and Peter. A look at Romero's original script for Day of the Dead has John described as another physically impressive black man whose Carribean accent is justified as the original film was meant to take place on a tropical island. In the actual film., John is not a very large man, and his 
strong Jamaican patois mostly serves to differentiate him as a laid-back, carefree man rather than Peter's tougher, streetwise American black man.

The next day, Sarah and Fisher are introduced to Logan's pet project, a captive zombie he calls "Bub." Logan has Bub demonstrate that zombies exhibit isolated incidents of memory; when he gives Bub a razor, he drags it along his cheek, shredding the decaying flesh. Rhodes and Steele interrupt, wanting to know what Logan is doing. When Bub sees Rhodes in a military uniform, he straightens and salutes. Logan is delighted, guessing that Bub was once a soldier, and tells Rhodes to salute back. When Rhodes refuses with disgust, Logan wonders how they are to set an example if they behave barbarically themselves. Logan defends his research claiming the zombies can be "tricked" into civilized behavior, just like us humans. Logan's insinuation here is complex; the implication is that civility comes from reward/punishment conditioning, which suggests that it is unnatural to behave in any way that does not benefit oneself directly. Thus, he is simultaneously arguing that Bub's behavior is more civilized than Rhodes, and that civilized behavior is inherently self-serving, like Rhodes (Paffenroth, 2006: 84). The distinction here is that while Rhodes is willing to go to any length to prove his domination over the others, Bub is able to practice restraint and grief as demonstrated by his failure to bite Logan when he has ample opportunity, and his mournful wail at discovering Logan's body later.

Back in the cave, soldiers are capturing more specimens. Miguel is still shaky and loses control of a zombie who kills two soldiers. Miguel flies into a rage screaming "it's not my fault" and winds up getting bitten on the forearm. Steele deals with the loose zombie while Sarah takes Miguel to John and Billy's trailer. In an effort to halt the 
zombifying effects of his bite, she desperately hacks off Miguel's arm with a machete and attempts to cauterize the wound with a torch. Steele and Rhodes arrive at the trailer to they want to avenge the two dead soldiers by killing Miguel. John and Sarah protect Miguel from the soldiers, offering to take responsibility for him, whatever his fate. When Sarah and Billy go to lab for morphine they watch Logan teach Bub to use a portable tape player. When Bub operates the controls properly, Logan gives him with a bucket of red meat, which he eagerly devours. Sarah and Billy realize with horror that Logan is rewarding Bub with fresh human meat, presumably that of the soldiers who just died at the zombie gate. Before they can intervene, Rhodes barges in and murders Logan.

Rhodes and Steele take Sarah and Fisher back to Billy and John's trailer at gunpoint, threatening to kill them if John refuses to flee the compound with the soldiers in the helicopter. When John refuses, Rhodes shoots Fisher. John points out that the chopper cannot hold them all, so the soldiers put Sarah and Billy in the zombie gate to solve that problem. Rhodes refuses, and pulls the trapdoor, exposing Sarah and Billy to the zombies in the dark cave. Sarah says she thinks there is a silo at the end of the cave, so they make a run for it. Steele attempts to beat John into compliance when they are interrupted by the sound of the platform elevator going up. A delirious Miguel has made his way to the surface of the compound, and has opened the gate, letting the mob of zombies in. When the zombies devour him on the elevator platform, he hits the controls, beinging the slaughter into the compound below. Amid the confusion, John is able to overwhelm Rhodes follow Sarah and Billy into the cave. Bub discovers the mangled body of Logan, and moans in pain before howling in anger. Zombies flood the halls, devouring the soldiers. In a hallway, Rhodes encounters Bub, who either remembers him 
from the lab incident or understands intuitively that Rhodes shot Logan. Bub stalks Rhodes as he crawls along the hall, shooting him in the arms and legs without fatally wounding him. In the end, Bub corners him in a room full of zombies. Bub salutes sarcastically and walks away as Rhodes is graphically disemboweled.

Sarah, Billy and John manage to survive in the cave, fighting off zombies with what little armament they have. When they reach the helicopter Sarah opens the door, and a zombie grabs her from inside. She screams and wakes up on a beautiful beach; she was dreaming again. John and Billy are fishing, demonstrating more John's ideals of more productive and restorative ways to spend time in the post-apocalyptic setting. Sarah pulls out a calendar and crosses off another day. It is a far less ominous ending than NOTLD, where none of the group survives, and DayOTD, where Peter and Fran have escaped with no plan and low fuel. Perhaps it is the serene, tropical setting that disappoints; in this way, DayOTD provides the closest thing to a happy ending of all the films in the series. Paffenroth points out that because of this last-minute dream sequence, audiences must wonder whether the events at the compound really occurred at all, or if they were just part of Sarah's nightmare (2006: 78). Thus, DayOTD lacks the exhilaration of an exciting story easily understood, but it remains a worthy and conceptually rich addition to the series.

As Tony Williams notes, the original screenplay written for Day of the Dead was quite different from the one that was made, due to budgetary restraints and Romero's unwillingness to compromise the film for an ' $R$ ' rating (2005: 131). Many of the subversive and oppositional elements of the original script found their way into 2005's Land of the Dead. The social commentary in the film is more subtle, if more complex; it 
almost requires an at least negotiated reading in order to appreciate the film. As with the other films in the series, a dominant/hegemonic reading would focus on the individual wrongdoings and weaknesses of specific characters, while ignoring the larger sociopolitical macro-perspective. Rhodes is obviously deranged and masochistic, as are Steele and Rickles, but Logan's madness contains nuanced implication of human nature. It strikes one as ironic that he and Rhodes were enemies when they apparently share a hunger for power and domination. His desire to discover how to control the zombies rather than how to "cure" or explain them is a point of contention between himself and Sarah.

The significance of this film has less to do with the social climate, and more to do with the development of Romero's series. Logan had Bub trained (or "tricked", to use his term) to refrain from attacking Logan, as his undead nature is prone to do. In a scene where Logan teaches Bub to operate a portable tape-player, Bub grabs Logans forearm but does not bite it; because of his behavioral conditioning, he does not bite the proverbial hand that feeds. Logan and Rhodes appear to be unable to cast off the vestiges of the previous social order, adhering to their roles as scientist and soldier respectively, without altering their duties to suit the changed circumstances. Arguably, this is due to a changed political climate since the 1960s; Phillips credits the aging "flower children" generation, who grew up in times of optimism and prosperity to an adulthood of economic disappointment and mistrust of political leaders (2005: 88). Just as Night of the Living Dead brought attention to socialized behaviors that hinder our survival as a species and Dawn of the Dead pointed out the emerging consumer culture as a symptom, Day of the Dead continues this line of reasoning by acknowledging our disastrous 
situation and asking "what now?" Day of the Dead argues that establishing a new society is impossible without completely rejecting every aspect of the previous social order.

This chapter has sought to provide a textual analysis of George A. Romero's Dawn of the Dead and Day of the Dead in line with the aforementioned method of inquiry, cultural materialism. While it has been shown that the films accommodate certain dominant Western stereotypes (gendered, class-based and racial), these films remain subversive due to their underlying implication that the current Western social condition is both untenable and self-destructive. The following chapter will conclude by outlining the most recent two films in the Dead series, and reiterating how the entire series pertains to a cultural materialist analysis of capitalism, consumerism and racism. 


\section{Chapter 4 - Conclusion}

Cultural materialism, as a method of analysis developed by Raymond Williams, seeks to describe the relationship between culture as it is depicted in literature and culture as it is lived among the majority of the working population. The focus is strictly descriptive, as Williams's initial aim was to deconstruct Marxist notions of an economic base determining the cultural superstructure; Williams sees the two as parts of an ongoing process of mediating and negotiating cultural production. Although popular culture is often believed to represent fickle and uncritical masses, Williams points out that because the dominant class controls the means of producing and distributing these cultural forms, ideological themes in popular culture are thus more representative of the principles of the elite rather than the lived reality of the majority (1958: 298). Horror films are especially interesting for cultural materialism because they are speculative by nature. In order for a film to explore the supernatural, it must examine that which is considered "natural," and why. As we have seen in chapter two, the monstrous zombies that appear in Romero's horror films have been constructed from historical accounts of the indigenous populations that were colonized and occupied by the West. The dazed Haitian Vodoun zombie was imbued with horror and cannibalism as per dominant discourses of racism and savagery. In this respect, the zombie is an appropriate villain for Western horror movies in that it represents a long-standing fear of the racialized other.

The fact that zombies are both animated yet dead speaks to the tension between these two states, inviting one to question the difference between life and death. Western horror movies often represent the living dead in the form of ghouls, vampires and zombies, each representing a violent and terrifying threat to the living. Within these 
undead monsters, the zombie is arguably the most menacing. The zombie lacks the weaknesses of vampires, such as sensitivity to sunlight, garlic and crucifixes. There are no superstitious devices to protect against the zombie onslaught. Like vampires who thrive on human blood, zombies hunger for the flesh of the living. Humanity is reduced to meat: the ultimate commodity, where one person's sustenance must come at the expense of the life of another. In addition to this obvious bodily threat to larger society, the zombie condition is contagious, and can be spread by a single bite. This context takes humanity from so-called civilization to the law of the jungle: eat or be eaten. Romero's last two films once again satirize the contemporary social condition while making implications about how our society might cope with the threat of the dead rising.

\section{I - George A. Romero's Land of the Dead and Diary of the Dead}

Since Day of the Dead, George A. Romero has added two more films to his Dead series; Land of the Dead and Diary of the Dead. The storyline of Land of the Dead takes place well after the zombie invasion, and depicts society reconstituted into exaggerated social stratification. The majority of the remaining population struggle to survive in poverty in the city, while the wealthy and powerful continue to live in luxury and security in a fortified high-rise building. The story centers on the conflict between soldiers Riley and Cholo, who are responsible for searching abandoned cities to gather salvageable goods. Cholo believes that by working hard and sucking up to his boss Kaufman, he can eventually afford a place in Fiddler's Green, the city fortress. Kaufman informs him that this is impossible, suggesting that it is a question of class rather than money. Cholo becomes a renegade and threatens to destroy Fiddler's Green unless Kaufman pays him 
$\$ 5$ million. Kaufman refuses to cooperate, saying "We don't negotiate with terrorists": a mischievous suggestion that Kaufman's rule of Fiddler's Green and the current American preoccupation with terrorism are not very different. In the end, Kaufman is killed by zombified Cholo, who was jilted enough in life to hold a grudge in undeath and hunt Kaufman. In a continuation of the "Bub" storyline from Day of the Dead, Land of the Dead features a gas attendant zombie who begins showing signs of sentience and intelligence. Identified by his name tag as "Big Daddy," this zombie shows anger at humans for killing his kind so recklessly, and is able to lead an army of zombies across the body of water separating them from the city. In the end, Fiddler's Green is overrun by Big Daddy and his army, who feast on the unprepared elite. . Paffenroth points out the link between the characters of Cholo and Big Daddy: a racially marginalized pair (Big Daddy was evidently a black man in life) who team up to bring down Kaufman's whitewashed capitalist enterprise (2006: 18). When Riley prepares to leave the city in Kaufman's tank, he has a clear shot at Big Daddy and the others. Riley looks through binoculars at Big Daddy, who looks back with his face looking simultaneously satisfied and beaten. Riley decides not to shoot them down, saying "They're just looking for a place to go" not unlike himself.

While the film contains obvious allegories to Western life in that it posits a society rebuilt much as society was before: stratified, racist and corrupt. There is social critique beyond the obvious in that the film predicts another unsustainable society: where the poor are sent to scavenge the old world rather than spending their time farming, or starting fresh (19). However, the film loses some of its context in its location in a hypothetical post-apocalyptic future; much of the poignancy of the Romero's films is due 
to their setting in contemporary Western society as it is being lived by its audience at the time. Thus, Land of the Dead's dystopian future allows us a distance that the previous films do not. Also, the "Big Daddy" storyline alters the previous films' emphasis on the actions and challenges of humanity in crisis. Now, we are made to contemplate the possibility of intelligent or conscious zombies, and how this might change our methods of dealing with them. That Riley chose not to destroy Big Daddy and his army suggests that humanity might be more usefully preoccupied with how to live with the zombies rather than how to destroy them. A dominant reading of this might emphasize the zombies as allegorical to racialized groups in the West, feared and reviled for misunderstood difference. While this allegory is a stretch since zombies pose a clear bodily threat to the entire human race, Riley's decision appears heroic and moralizing, as though he were emancipating the undead.

Diary of the Dead was built upon a completely different concept; using a cinematic technique popularized by the Blair Witch Project (1999), the film is presented to the audience as an amateur documentary of the zombie onslaught made by a group of college film students. The storyline begins as the group hears news reports of the dead rising, and decides to abandon campus to go home to their families. One student, Jason, is determined to film their entire experience from beginning to end much to the irritation of the others, especially his girlfriend Debra. The group makes their way to Debra's house where they discover her undead family, whom they destroy. They wind up at a wealthy friend's house, where they take refuge in the panic room. The film ends with the group of ten being whittled down to three. After Jason's death, Debra changes her mind about Jason's footage and vows to complete his film so that people will know "the truth." 
The film is a worthy addition to Romero's Dead series in that it makes use of modern communication technologies that have become a large part of contemporary Western culture; cellular phones and the internet were not yet available when the previous films were made. The central theme of the Diary of the Dead is the group's quest for "the truth," meaning accurate information of the crisis at hand. In the age of computer-generated imaging (CGI) and photo-editing, the old adage "pictures don't lie" has come under scrutiny. The group learns that the news provided by the mainstream media (ie- television and radio) is largely inaccurate and misleading, due to the governments' attempt to maintain social authority by altering footage and depicting the situation as under control. Much of the information the group learns about the undead rising comes from the internet: specifically, the site YouTube.com where users are able to post video clips which are then accessible to anyone online. Jason's obsession with filming their "reality" for others to know their story is an effort to disseminate honest information about the undead rising.

\section{II - Conclusion}

The preceding chapters have sought to investigate the ways in which the first three films of the Dead series by George A. Romero can be interpreted as social commentary on several aspects of Western life: most notably community, consumption and authority. Through cultural materialism, the analyses of these films has focused on the tensions between culture as it is lived and culture as it is depicted in film, with a Marxist emphasis on class and exploitation. This thesis has endeavored to demonstrate 
that these films can become mechanisms for critical thinking among an active audience by satirizing Western economic systems and social conditions.

What makes Night of the Living Dead a good movie is its ability to engender sympathy with and for the characters; we learn the nature of the zombie threat as they do, and we share their terror and confusion. What makes it an important movie, and unique within its genre is its focus on people coping with the monster as opposed to the monster itself. As the film series goes on more attention is paid to zombie psychology and the possibility of zombie evolution, but, in the beginning, the zombies are not so much villainous as they are vehicles for demonstrating the villainy of humanity. The audience is not given much information on the backgrounds of the characters, but it is still made to feel like they "know" Barbra, Ben and Harry through their actions and reactions to the crisis. Many post-apocalyptic films speculate on human organization and crisis management, but NOTLD delves deeper into the Westernized psyche: with storylines centering on racial tensions and gendered stereotypes. As mentioned in the second chapter, a review of the plotline reveals that every character's death is the result of a Western social ritual or taboo, as opposed to being outsmarted by the zombies, or simply overpowered physically. This provides the audience a unique perspective into how we live, and what we should really fear as a society.

The satire in Dawn of the Dead is both more poignant and overt. It is the story of a group of people attempting to hide in a shopping mall full of supplies, and discovering that the material goods Westerners spend their lives accumulating do not count for much when the shit hits the fan. DawnOTD was released in 1978, capping off a decade marked by widespread mistrust of government (due to Nixon's resignation) as well as the worst 
economic conditions since the Great Depression. Both these historical facts are touched upon through the film's depiction of preoccupation with hoarding material goods and supplies, and the media's deliberate misinformation. As in NOTLD, the characters in DayOTD must grapple with socialized obstacles to their survival; race relations again, and also stereotypes of masculinity and femininity. The shopping mall becomes less a safe haven and more a hoard of necessary supplies that must be defended. The film has sparked numerous debates in online forums as to where the best hiding places would be should a zombie invasion strike. This fact alone points to the film's role in inspiring critical thought about disaster preparation. Day of the Dead contains more philosophical insight into the zombie epidemic situation, speculating as to the meaning of life after such a crisis has occurred. Scientists attempt to diagnose and explain while military seeks to maintain control and authority, and the film questions the usefulness in these endeavors. The subplot of "Bub," a zombie that demonstrates the ability to be tamed and domesticated highlights discourses of savagery and civilization; zombies are understood to be murderous by nature, but the violent soldiers show that humans are not so different.

The main theme underlying all these films is one of satire and critique of the Western social condition of racism, consumerism and the perpetual struggle for social control. What these films illustrate is that these elements which preoccupy North American life count for very little in the event of disaster; in fact, they greatly lessen our ability to survive such catastrophe. In the contemporary Western context of the American "war on terror" and natural disasters such as the devastation of New Orleans due to hurricane Katrina, the themes explored in these films are all the more relevant. The active, critical viewer will recognize the parallels between the disastrous events in these 
films and the current state of Western social life. As such, the films confront dominant understandings of Western culture and challenge assumptions of security, progress and economic policy. The question of whether or not such subversive films can inspire tangible action remains to be seen; the Zombie Walks grow in participation and popularity each year, and although they are not explicitly political, they do point to an increasing awareness of the relevance of the social commentary presented in these films. Cultural materialism seeks to examine the tensions between culture as it is lived and culture as it is depicted in cultural texts. This thesis has sought to argue that there is more to George A. Romero's Dead series than monsters, screams and gore. These films take the current social condition as given (a supposedly thriving and affluent Western society) and demonstrate that this position rests upon a fragile foundation that can only support it to a certain degree. While a zombie apocalypse is exceedingly unlikely, one can substitute the zombie attack in these movies for a number of social or environmental crises and still make for an important and thought-provoking film. As per active audience theory, the meanings of these films are in the eye of the beholder, and any argument that these movies are subversive can be legitimately contested by the critical viewer who sees things differently. This thesis is not meant to insist on the perspective of the textual analyses presented; rather, it has sought to describe how these films contribute to an understanding of the relationship between lived culture and perceived culture. In drawing attention to the self-destructive nature of capitalism, consumerism and racism, Romero's films enable a critical, reflexive look at the current Western social condition while targeting a different audience demographic than, say, a documentary would. As such, it warrants academic scrutiny as much as any piece of literature, drama or visual art 
that is deemed socially important, as the National Film Registry recognizes. As Raymond Williams emphasized, the relationship between popular culture and culture as it is lived is one of constant tension, with meanings being continually negotiated and renegotiated. While some meanings are picked up, others are ignored in an unpredictable process of audience interpretation. This thesis has sought to emphasize the potential of the films to be read with their intended meaning, as demonstrated by director commentaries, and the importance of the interpretive agency of an active audience.

These films are morbidly critical. They are not hopeful, optimistic or inspiring. They do not lure the audience into revolutionary ideologies, nor do they set out a concrete plan of action. Their purpose, and their glory, is descriptive and not prescriptive. Contemporary Western social existence has been long marked by fear: fear of nuclear war, of economic recession, of untrustworthy leaders and racialized groups. George A. Romero turns the lens of inquiry inward, to Western social life, highlighting a more sinister threat that lies much closer to home. Romero is not the harbinger of a new Marxist revolution through his films, but his suggestion that we may be that which we fear the most is nothing short of radical. 


\section{Bibliography}

Austin, Bruce A. 1997. "Researching Film and Television Audiences." The Eye of the Beholder. Eds Gary Edgarton, Michael T. Marsden and Jack Nachbar. Bowling Green; State University Popular Press (pp. 85-96)

Bartolovich, Crystal. 1998. "Consumerism, or the Cultural Logic of Late Cannibalism" in Barker, Hulme and Iverson (Eds) Cannibalism and the Colonial World. Cambridge: Cambridge University Press (pp. 204 - 237)

Brooker, Will and Deborah Jermyn. 2003. (Eds.) The Audience Studies Reader. London; Routledge.

Davis, Wade. 1988. Passage of Darkness: the Ethnobiology of the Haitian Zombie. Chapel Hill: University of North Carolina Press.

Elsaesser, Thomas. 1989. "Social Mobility and the Fantastic," in James Donald, ed., Fantasy and the Cinema. London; BFI (pp. 23-38)

Fox, R. 1937. The Novel and the People. London; Lawrence and Wishart (1979)

Giroux, Henry A. 2002. Breaking in to the Movies; Film and the Culture of Politics. Malden; Blackwell Publishers.

Gramsci, Antonio. 1971. Selections from the Prison Notebooks. London; Lawrence and Wishart.

Higgins, John. 1999. Raymond Williams: Literature, Marxism and Cultural Materialism. London; Routledge.

Hulme, Peter. 1998. "Introduction: The Cannibal Scene" in Barker, Hulme and Iverson (Eds) Cannibalism and the Colonial World. Cambridge: Cambridge University Press (pp. 1-38)

Jancovich, Mark. 2002. Horror: The Film Reader. London; Routledge.

Jones, Alan. 2005. The Rough Guide to Horror Movies. London; Penguin.

Leavis, F.R. 1962. The Great Tradition. Hammondsworth; Penguin.

Maddrey, Joseph. 2004. Nightmares in Red, White and Blue: The Evolution of the American Horror Film. Jefferson, North Carolina: McFarland \& Company Inc.

Marx, Karl. 1970. "The Factory" in Capital Vol. 1. London: Lawrence and Wishart. 
Modleski, Tania. 1986. Studies in Entertainment: Critical Approaches to Mass Culture. Bloomington: Indiana University Press.

Morley, David. 1992. Television, Audiences \& Cultural Studies. New York: Routledge.

National Film Registry. Jan $4^{\text {th }}$ 2008. National Film Preservation Board (Library of

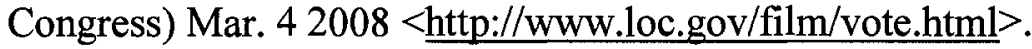

Newman, Kim. 1988. Nightmare Movies: A Critical Guide to Contemporary Horror Films. New York: Harmony Books.

Obeyesekere, Gananath. 2005. Cannibal Talk: The Man-Eating Myth and Human Sacrifice in the South Seas. Berkely and Los Angeles, California: University of California Press.

Paffinroth, Kim. 2006. Gospel of the Living Dead: George A. Romero's Visions of Hell on Earth. Waco: Baylor University Press.

Petrinovich, Lewis F. 2000. The Cannibal Within. New York: Walter de Gruyter Inc.

Phillips, Jerry. 1998. "Cannibalism qua Capitalism: the Metaphorics of Accumulation in Marx, Conrad, Shakespeare and Marlowe" in Barker, Hulme and Iverson (Eds) Cannibalism and the Colonial World. Cambridge: Cambridge University Press (pp. 183-203)

Phillips, Kendall R. 2005. Projected Fears: Horror Films and American Culture. Westport: Praeger Publishers.

Pinedo, Isabel Cristina. 1997. Recreational Horror: Women and the Pleasures of Horror Film Viewing. Albany; State University of New York Press.

Rojek, Chris. 2003. Stuart Hall. Polity Press.

Staiger, Janet. 2005. Media Reception Studies. New York; New York University Press.

Tudor, Andrew. 1989. Monsters and Mad Scientists: A Cultural History of the Horror Movie. Oxford; Basil Blackwell.

Williams, Raymond. 1963. Culture and Society 1780-1950. London; The Hogarth Press (1958)

Williams, Raymond. 1979. Politics and Letters: Interviews with New Left Review. London; New Left Books. 
Williams, Raymond. 1980. Problems in Materialism and Culture. Great Britain; Redwood Burn Ltd.

Williams, Tony. 2003. The Cinema of George A. Romero: Knight of the Living Dead. London \& New York; Wallflower Press.

Wood, Robin. 1979. American Nightmare: Essays on the Horror Film. Toronto; Festival of Festivals.

\section{Filmography}

28 Days Later. 2002. Fox Searchlight Pictures.

A Trip to the Moon. 1902. Gaston Méliès.

Alien. $1979.20^{\text {th }}$ Century Fox.

The Blair Witch Project. 1999. Artisan Entertainment.

Bram Stoker's Dracula. 1992. Sony Pictures Entertainment.

Children of the Living Dead. 2001. Spartan Home Entertainment.

Dawn of the Dead (DVD). [1978] 2004. Commentary by George A. Romero, Tom Savini, Chris Romero and Perry Martin. The MKR Group, Inc.

Dawn of the Dead. 2004. Universal Pictures.

Day of the Dead (DVD). [1985] 2006. Commentary by George A. Romero, Tom Savini, Cletus Anderson and Lori Cardille. United Film Distribution Company.

Day of the Dead 2: Contagium. 2005. Anchor Bay Entertainment.

Diary of the Dead (DVD). 2008. Voltage Pictures.

Dracula. 1931. Universal Pictures.

The Evil Dead. 1981. New Line Cinema.

Ghost. 1990. Paramount Pictures.

Frankenstein. 1931. Universal Pictures.

Halloween. 1978. Compass International Pictures. 
Hell of the Living Dead. 1980. Anchor Bay.

The Hills Have Eyes. 1977. Vanguard.

I Walked With a Zombie. 1943. RKO Radio Pictures Inc.

Interview with the Vampire. 1994. Warner Bros.

Invasion of the Body Snatchers. 1956. Allied Artists Pictures Corporation.

Land of the Dead (DVD). 2005. Universal Pictures.

Night of the Creeps. 1986. TriStar Pictures.

Night of the Living Dead (DVD). [1968] 1999. Commentary by John A. Russo, Bill Hinzman, Russ Streiner and Bob Michelucci. The Walter Reade Organization.

Night of the Living Dead. 1990. $21^{\text {st }}$ Century Film Corporation.

Night of the Living Dead 3D. 2006. Lux Digital Pictures.

Psycho. 1960. Universal Pictures.

Resident Evil. 2002. Screen Gems.

Resident Evil: Apocalypse. 2004. Screen Gems.

Resident Evil: Extinction. 2007. Screen Gems.

The Return of the Living Dead. 1985. Orion Pictures Corporation.

Return of the Living Dead Part II. 1988. Lorimar Pictures.

Return of the Living Dead 3. 1993. Trimark Pictures.

Return of the Living Dead: Necropolis. 2005. Denholm Trading Inc.

Return of the Living Dead: Rave from the Grave. 2005. Denholm Trading Inc.

Tarantula. 1955. Universal International Pictures.

The Texas Chainsaw Massacre. 1974. Bryanston Distributing Company.

Them! 1954. Warner Bros.

The Thing from Another World. 1951. RKO Radio Pictures Inc. 
Tombs of the Blind Dead. 1971. Blue Underground.

White Zombie. 1932. United Artists.

Zombi 2. 1979. Anchor Bay Entertainment. 